\title{
A new genus of coccolepidid fishes (Actinopterygii, Chondrostei) from the continental Jurassic of Patagonia
}

\author{
Adriana López-Arbarello, Emilia Sferco, and Oliver W.M. Rauhut
}

\begin{abstract}
Jurassic freshwater fish faunas are still poorly known, with the only assemblage of that age known from southern South America being the "Almada fauna" of the Cañadón Calcáreo Formation (Oxfordian-Tithonian) of Chubut, Argentina. This fauna is composed mainly by abundant teleosts and a much rarer basal actinopterygian, originally described as †Oligopleurus groeberi and currently usually placed in the genus $\dagger$ Coccolepis. This taxon is here redescribed on the basis of the original specimens and more numerous and better preserved new material from several localities within the Cañadón Calcáreo Formation. The species shows several differences to other coccolepidid taxa, including the apomorphic presence of a sensory canal in the gular plate, and cannot be referred to a known genus. Thus, a new genus name, †Condorlepis gen. nov., is proposed. The detailed anatomical description of + Condorlepis gen. nov. groeberi provides further evidence for the chondrostean affinities of the Coccolepididae and their close relationships with the Acipenseriformes, since this species shows six characters that were hitherto considered to be autapomorphies of the latter clade. A comparison of the Almada fauna with other Gondwanan Jurassic freshwater fish faunas shows close similarities with the roughly contemporaneous fauna of Talbragar, Australia, which also includes an abundant basal teleost and coccolepidids. In contrast, there are marked differences with the faunas of the Early to Middle Jurassic Kota Formation of India, the Late Jurassic to Early Cretaceous Stanleyville beds of the Democratic Republic of the Congo, and the probably Late Jurassic Tacuarembó Formation of Uruguay, in which basal, non-teleostean neopterygians and sarcopterygians are abundant.
\end{abstract}

Adriana López-Arbarello. Bayerische Staatssammlung für Paläontologie und Geologie, Richard-WagnerStrasse 10, D-80333 München, Germany. E-mail: a.Lopez-Arbarello@Irz.uni-muenchen.de and Museo Paleontológico Egidio Feruglio, Av. Fontana 140, 9100 Trelew, Argentina Emilia Sferco. Laboratorio de Paleontología Evolutiva de Vertebrados, Departamento de Geología, Facultad de Ciencias Exactas y Naturales, Universidad de Buenos Aires, Ciudad Universitaria, Pabellón II, 1428 Buenos Aires, Argentina emiliasferco@gmail.com and Museo Paleontológico Egidio Feruglio, Av. Fontana 140, 9100 Trelew, Argentina Oliver W.M. Rauhut. Bayerische Staatssammlung für Paläontologie und Geologie, Richard-WagnerStrasse 10, D-80333 München, Germany o.rauhut@Irz.uni-muenchen.de 
and Museo Paleontológico Egidio Feruglio, Av. Fontana 140, 9100 Trelew, Argentina and Department of Earth and Environmental Sciences and GeoBioCenter, Ludwig-Maximilians-University, Richard-Wagner-Strasse 10, 80333 Munich, Germany

Keywords: New genus; Chondrostei; Coccolepididae; Patagonia; Upper Jurassic; freshwater fishes

\section{INTRODUCTION}

Due to a bias in the fossil record, Jurassic freshwater fish faunas are rather scarce and only a few are known worldwide: several poorly known fish assemblages in Asia (Chang and Miao, 2004) and North America (Wilson and Bruner, 2004), the fish assemblages from the Morrison Formation (Kimmeridgian-Tithonian) in the USA (Kirkland, 1998), the fishes from the Early Jurassic Kota Formation, India (Prasad et al., 2004), the continental sequence of the Late Jurassic to Early Cretaceous Stanleyville Beds, Democratic Republic of the Congo (Myers et al., 2013), the Talbragar Beds (Tithonian) in Australia (Woodward, 1895), the Tacuarembó Formation in Uruguay (Late Jurassic-earliest Cretaceous?; Soto et al., 2012), and the Cañadón Calcáreo Formation (Oxfordian-Tithonian) in central Chubut in Argentina (LópezArbarello et al., 2008).

The Almada Fauna is preserved in the lowermost part of the Cañadón Calcáreo Formation (Oxfordian-Tithonian) and it is mainly composed of very well-preserved and abundant teleosts, representing a single species, and numerous specimens representing a small chondrostean. Other actinopterygians, probably non-teleostean neopterygians, are also present, but much less represented and poorly preserved. The present article is focused on the study of the chondrosteans from the Almada Fauna, which were originally described as †Oligopleurus groeberi Bordas, 1943, and later moved to the genus †Coccolepis (Bocchino, 1978).

López-Arbarello et al. (2002) first reported on the close phylogenetic relationships between coccolepidids (including †Coccolepis bucklandi and †"Coccolepis" groeberi, the latter representing a new genus, described herein) and the Acipenseriformes, and Hilton et al. (2004) also suggested possible affinities of †Coccolepis with the chondrosteans as defined by Patterson (1982), i.e., the group including the Acipenseriformes (sturgeons and paddlefishes) and their fossil relatives. The history of acipenseriforms can be traced back to the Early Jurassic (Hilton and Forey, 2009). The history of the two recent acipenseriform families
Polyodontidae and Acipenseridae is known back to the Early Cretaceous ( Hauterivian; Grande et al., 2002) and Middle Jurassic (Choudhury and Dick, 1998), respectively. However, the fossil record of the group is very patchy, especially in Mesozoic rocks, and, except for a few recently revised species (Grande and Bemis, 1991; Grande et al., 2002; Grande and Hilton, 2006), most of the other fossil taxa are rather poorly understood (Hilton and Grande, 2006). The fossil relatives of the Acipenseriformes within Chondrostei are still debated and not well established (Stensiö, 1921, 1932; Nielsen, 1949; Patterson, 1982; Grande and Bemis, 1996). Pending a cladistics analysis of the relationships of †"Coccolepis" groeberi, this contribution is dedicated to the taxonomy of this basal chondrostean from the Jurassic of Patagonia, including the description of the new genus and a discussion of its systematic position. A comparison between the Almada Fauna and the other Jurassic freshwater ichthyofaunas is also included.

Institutional abbreviations. MACN, Museo Argentino de Ciencias Naturales "Bernardino Rivadavia," Buenos Aires, Argentina; MPEF-PV, Vertebrate paleontology collection at the Museo Paleontológico Egidio Feruglio, Trelew, Argentina.

Anatomical abbreviations: ao, antorbital bone; ang, angular bone; a.p.psph, anterior process of parasphenoid; br, branchiostegal ray; cl, cleithrum; cla, clavicle; c.fu, caudal fulcra; d, dentary; d.a, dorsal arcual ossification; dpt, dermopterotic; dsph, dermosphenotic; e, epural; ex, extrascapular bone; fr, frontal; fr.fu, fringing fulcra; gu, gular plate; h1, first hypural; h.a, haemal arch; h.s, haemal spine; hy, hyomandibular bone; io, infraorbital bone; io.c, infraorbital sensory canal; m.c, mandibular sensory canal; $\mathbf{m} . \mathbf{r}$, middle radial; $\mathbf{m x}$, maxilla; na, nasal bone; n.a, neural arch; op, operculum; pa, parietal bone; pcl: postcleithrum; php, parhypural; pmx, premaxilla; pop, preoperculum; pp, parapophysis; p.r, proximal radial; pro, postrostral bone; psp, parasphenoid; ptt, posttemporal bone; r, radials; ro, rostral bone; s, scale; scl, supracleithrum; sct, scute; sn, supraneurals; so.c, supraorbital sensory canal; sop, suboperculum; sr, 


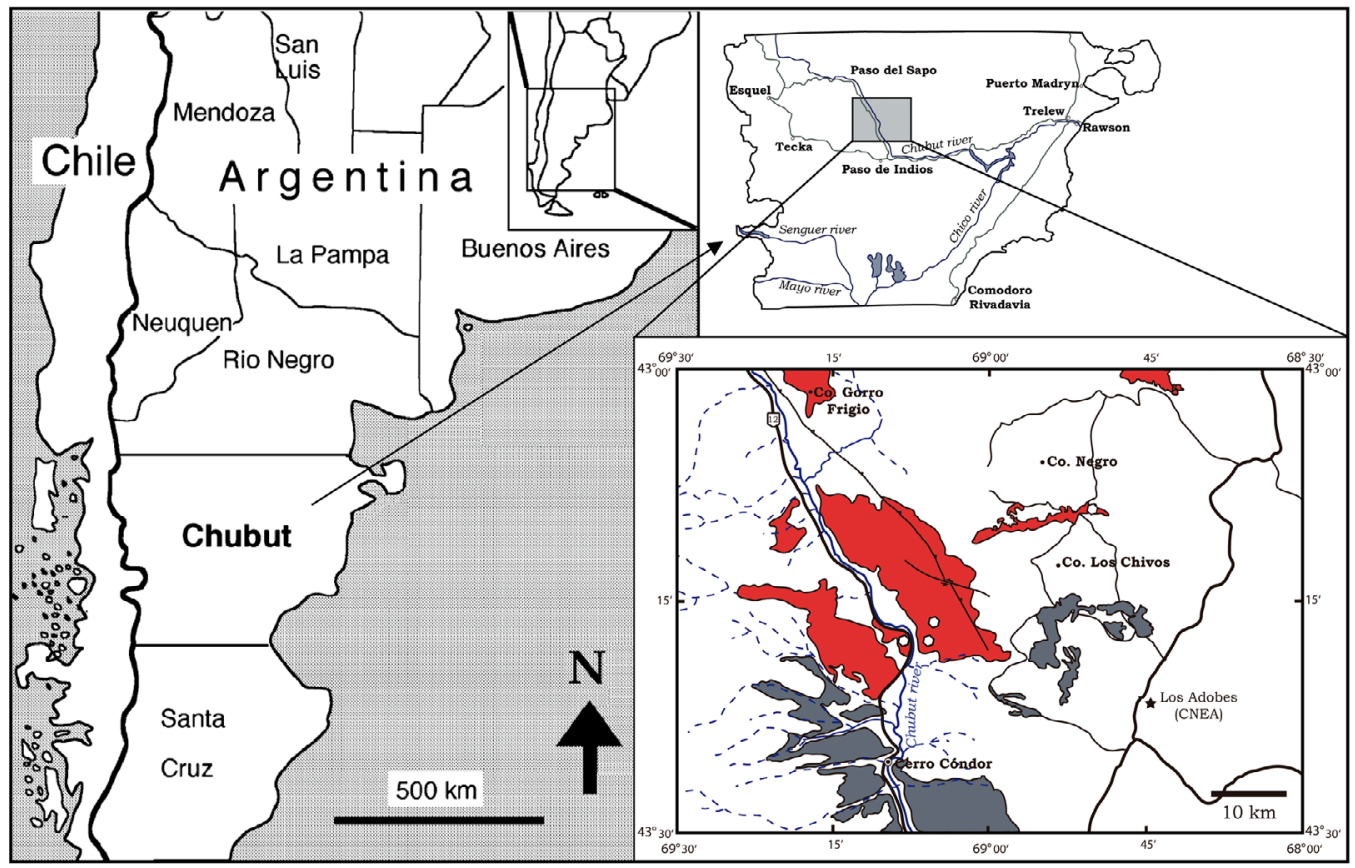

FIGURE 1. Geographic location and extension of the outcrops of the Cañadón Calcáreo Formation (represented in red) and the Cañadón Asfalto Formation (represented in dark gray) in the Chubut province, Patagonia, Argentina. The white spots on the outcrops of the Cañadón Calcáreo Formation in the detailed map on the bottom right represent the main fish localities, which are precisely indicated in Figure 2.

sclerotic ring; v.a, ventral arcual ossification. An 'l' and ' $r$ ' between brackets after the abbreviations indicates left and right elements, respectively.

\section{GEOLOGICAL SETTINGS}

The fishes belong to the so-called Almada fauna (López-Arbarello et al., 2008) of north-central Chubut province. The type locality of this fauna is placed at Puesto Almada, Estancia El Torito, some $20 \mathrm{~km}$ north of the village of Cerro Cóndor, at the Ruta Provincial $\mathrm{N}^{\circ} 12$ in the valley of the Chubut River (Figure 1, Figure 2). Although the "estratos de Almada" (Almada beds) have long been known for their abundant and well-preserved fishes (Piatnitzky, 1936; Bordas, 1943; Bocchino, 1967, 1978), their exact stratigraphic placement and referral to a geological unit have so far remained controversial. Sometimes considered to be a local unit of Late Cretaceous age (e.g., Tasch and Volkheimer, 1970; Bocchino, 1978), they have recently often been included in the Cañadón Asfalto Formation (e.g., Turner, 1983; Silva Nieto et al., 2002; Cabaleri et al., 2010a, 2010b), a mainly lacustrine unit that is widely exposed further south along the Chubut River valley (Stipanicic et al., 1968; Figure 1) and to which a Middle-Late Jurassic (Callovian-Oxfordian) age has traditionally been assigned (Tasch and Volkheimer, 1970; Page et al., 1999; Silva Nieto et al., 2002).

The "estratos de Almada" are part of the infillings of the Cañadón Asfalto Basin, a large-scale hemigraben structure that developed in the course of the initial rifting of the supercontinent of Gondwana during the Triassic and Early Jurassic and suffered some compressive stresses in the Neogene (Figari and Courtade, 1993; Figari, 2005). Figari and Courtade (1993; see also Page et al., 1999; Figari, 2005) subdivided the sedimentary infill of this basin in a sequence stratigraphic approach into four megasequences (megasequence 0 to megasequence III), representing different phases in the evolution of the basin, with sediments and volcanic rocks ranging from the Early Jurassic to the Late Cretaceous. According to their scheme, the "estratos de Almada" belong to megasequence II, whereas the Cañadón Asfalto Formation sensu Stipanicic et al. (1968) belongs to the megasequence I, with both sequences being separated by a slight angular unconformity. These authors accepted the Callovian-Oxfordian age for the megasequence I (Cañadón Asfalto Formation sensu Stipanicic et al., 1968), but argued for a latest Jurassic to Early Cretaceous age for their megasequence II, citing biostratigraphic evidence from unpublished internal reports of the oil com- 


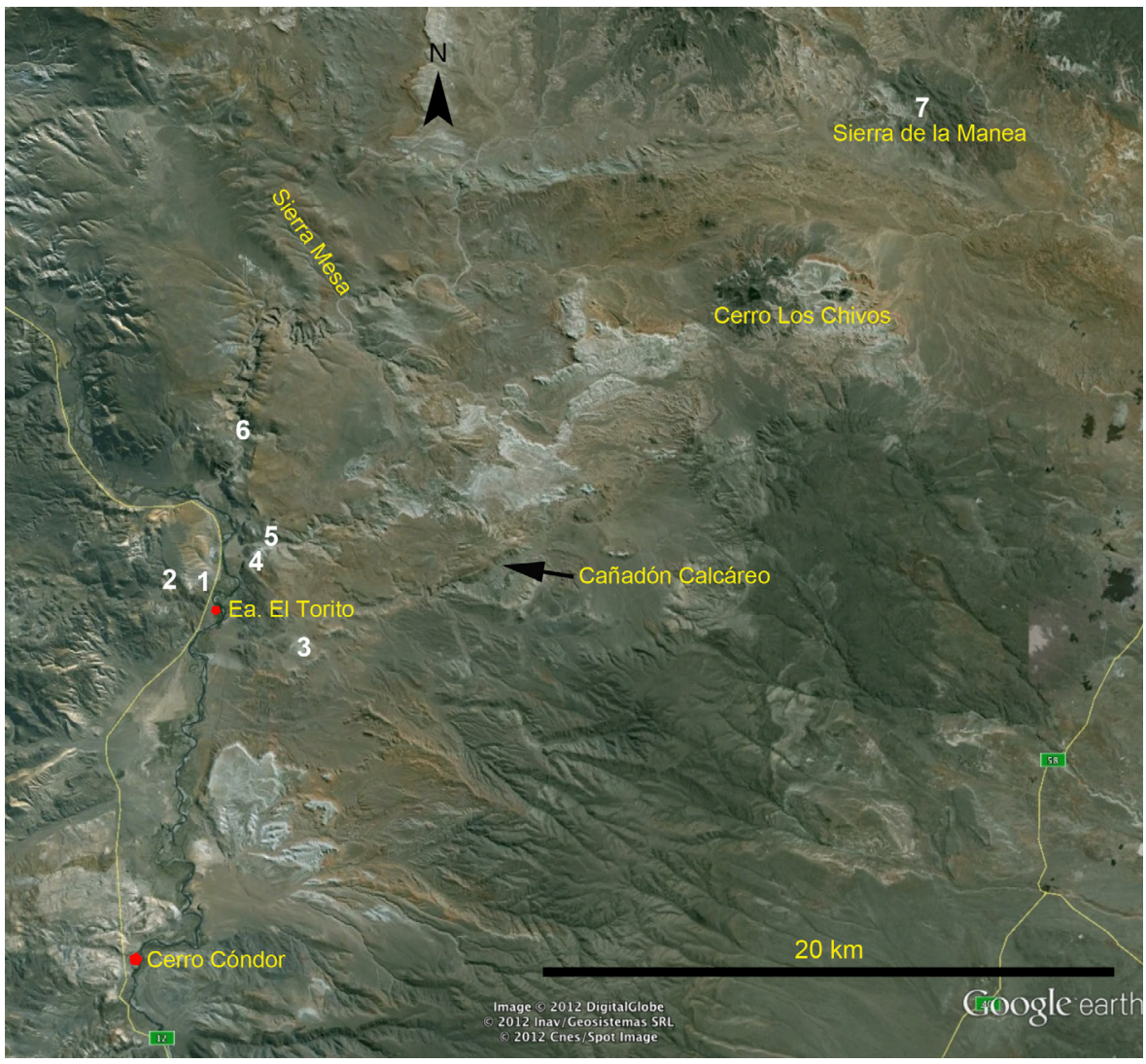

FIGURE 2. Geographic location of the fish localities: 1, Puesto Almada; 2, Punta Biotita; 3. Estancia Limonao; 4, Cañadón Los Chivos 1; 5, Cañadón Los Chivos 2; 6, Cañadón Las Minas; 7, La Manea. Geographic information was drawn on a Google earth image (@ 2012 Digital Globe).

pany YPF as source for this date. Confusingly, Figari and Courtade (1993) nevertheless used the name "upper section of the Cañadón Asfalto Formation" for this unit.

Silva Nieto et al. (2002) also maintained the "estratos de Almada" in the Cañadón Asfalto Formation, but argued that the lower and upper section of this formation were concordant and both represented a Callovian-Oxfordian age. The two sections were formally denominated as Las Chacritas and Puesto Almada Members, respectively, by Silva Nieto et al. (2003), and this scheme was followed by Cabaleri et al. (2005, 2010a, 2010b), Cabaleri and Armella (2005), and Gallego et al. (2011). However, these authors noted an increasing discordance in age between the two members, with new bio- and chronostratigraphic evidence indicating a Bajocian-Bathonian age for the Las Chacritas Member (Volkheimer et al., 2008; Cabaleri et al., 2010b) and an Oxfordian-Tithonian age for the Puesto Almada Member (Cabaleri et al., 2010a, 2010b; Gallego et al., 2011). Neverthe- less, both members were maintained in the Cañadón Asfalto Formation.

In a geological study of an area northeast of the type locality of Puesto Almada, Proserpio (1987) defined a new geological unit, the Cañadón Calcáreo Formation, of presumably Late Jurassic to Early Cretaceous age. Though they maintained the denomination as "upper section of the Cañadón Asfalto Formation," Figari and Courtade (1993) noted that this Cañadón Calcáreo Formation is equivalent to their megasequence II, in which they also included the "estratos de Almada" (see also Cortiñas, 1996; Page et al., 1999; Figari, 2005). Following this revision, and based on own observations in the field, Rauhut (2003, 2006a, 2006b), López-Arbarello (2004), Rauhut et al. (2005), López-Arbarello et al. (2008), and Carballido et al. (2011) referred to this unit as Cañadón Calcáreo Formation, including the "estratos de Almada" (Figure 1). Although Volkheimer et al. $(2008,2009)$ accepted the referral of the "estratos de Almada" to the Cañadón Calcáreo Formation, assigning an Early Cretaceous (Valanginian) age 
to this unit based on palynological evidence from the type section of this unit, the same authors later (Cabaleri et al., 2010a; Gallego et al., 2011) returned to the use of the name "Puesto Almada Member of the Cañadón Asfalto Formation" for the "estratos de Almada." The argument for this change was that a Late Jurassic (Tithonian) chronostratigraphic date obtained from the type locality at Puesto Almada (Cabaleri et al., 2010b) was at odds with the assumed Early Cretaceous age of the Cañadón Calcáreo Formation. Curiously, however, they did not apply the same logic to the conflicting dates of the Las Chacritas and Puesto Almada members, though the time difference between the radiometric Tithonian age of Puesto Almada and the assumed Valanginian age of the type section of the Cañadón Calcáreo Formation is considerably less than that between the former and the radiometrically obtained Bajocian-Bathonain age for the Las Chacritas Member ( $\approx 9$ m.y. versus $\approx 20$ m.y.; Gradstein et al., 2004) of the Cañadón Asfalto Formation.

Extensive fieldwork in the Jurassic rocks of the middle Chubut valley by one of us (OWMR) in collaboration with the Museo Paleontológico Egidio Feruglio in the past 12 years has yielded new data on the geology of the "estratos de Almada," their distribution and their assignment to a certain geological unit. First, larger scale excavations in the classical fish localities at Puesto Almada and Estancia Limonao, on the other side of the Chubut River (Figure 2), confirmed that the main fish beds exposed in these two localities represent the same layer. Furthermore, the Almada fish beds were found to crop out in many places along the eastern bank of the Chubut River between Estancia Limonao and the Cañadón Las Minas (Figure 2). The succession of the geological sequence containing the fish beds is equivalent in all of the localities, though the thickness of the different layers may vary, probably due to deposition on an existing paleorelief of rocks of the Lonco Trapial Group. In places where the contact with the underlying unit is exposed, such as in a small canyon west of Puesto Almada and at the entrance of the Cañadón Los Chivos, the sequence starts with a coarse conglomerate that unconformably overlies the Lonco Trapial Group. The conglomerate is an orthoconglomerate composed of angular to well-rounded clasts of reworked Lonco Trapial Group and varies considerably in thickness. The lower part of the sequence above the conglomerate is dominated by lacustrine shales and mudstones, with intercalations of sandstones and tuffites. The fish beds are placed in the upper part of this section. Thick sandstone channels a few meters above the fish beds mark the change to more fluvial conditions in the upper part of the sequence, which is dominated by sandstones (often with channel structures and cross-bedding), tuffites and tuffs. This general sequence is equivalent to that of the Cañadón Calcáreo type locality (see Volkheimer et al., 2009), and a visit to this locality in 2009 also led to the discovery of fish remains in the lacustrine shales in the lower part of this section. Furthermore, we collected samples of tuff layers at Puesto Almada and the Cañadón Calcáreo type locality that yielded equivalent ages of c. 157.4 Ma (Oxfordian; Cúneo et al., 2013). Finally, Zavattieri et al. (2010) analyzed more extensive palynological samples from the Cañadón Calcáreo type section and came to the conclusion that the latter is no younger than Tithonian in age. Thus, we consider the "estratos de Almada" to be equivalent to the Cañadón Calcáreo Formation of Proserpio (1987). Volkheimer et al. (2009) argued that the Cañadón Calcáreo Formation at its type locality is overlain in an erosional unconformity by the Chubut Group. However, our own observations in the field indicate that this presumed unconformity actually represents a local formation of an erosional basis of a river channel and cannot be traced laterally over larger distances. Thus, we consider all of the rocks at the Cañadón Calcáreo type locality to represent the same sedimentological sequence, as did Proserpio (1987) and Figari (2005), with the latter assigning a total thickness of some $1400 \mathrm{~m}$ to this profile.

Regardless of the referral of the Almada fauna to a particular geological unit, a Late Jurassic age for this fauna can by now be regarded as well established. Analysis of a tuff some $30 \mathrm{~m}$ above the fish beds from the locality Punta Biotita (Figure 2 ), in a small canyon west of Puesto Almada, resulted in a Tithonian age $(147 \pm 3 \mathrm{Ma}$; Khoukarsky, personal commun. in Rauhut, 2006b), which is identical to an age reported from the type locality by Cabaleri et al. (2010a; this date might refer to the same tuff sample as the date noted by Rauhut [2006a], since these authors note that the sample for dating was provided by $O$. Rauhut. In this case, the sample is not derived from Puesto Almada, as noted by Cabaleri et al., but from a locality some $1000 \mathrm{~m}$ further to the west). On the other hand, dating of a tuff collected by one of us (OWMR) in the Puesto Almada area, also some 50 $\mathrm{m}$ above the fish beds, resulted in an uppermost Oxfordian-lowermost Kimmeridgian age (Cúneo et 
3.1

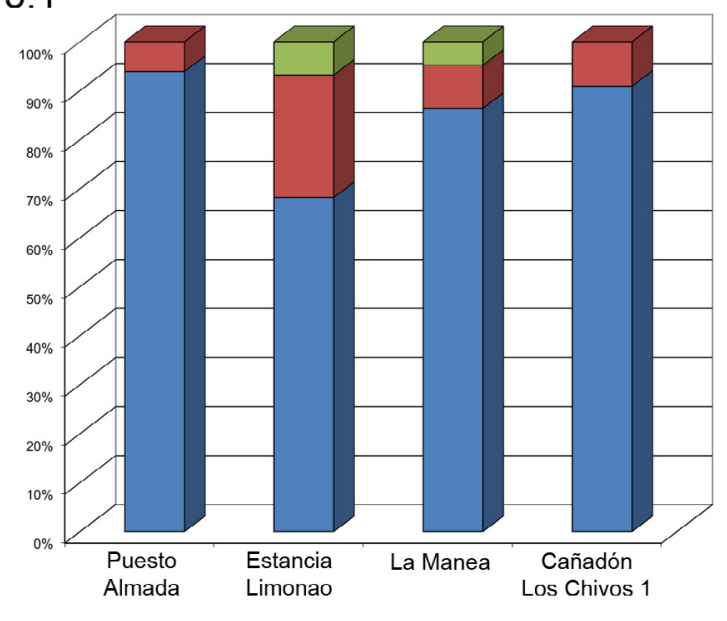

Teleosts
3.2

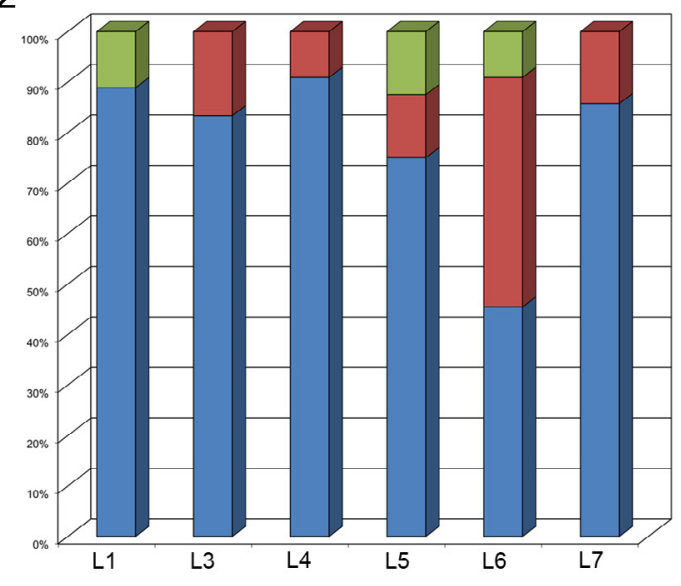

Coccolepidids

Other actinopterygians

FIGURE 3. Relative abundance of the main fish groups represented in the Cañadón Calcáreo Formation. 3.1, General taxonomic composition in four of the different localities: Puesto Almada: $n=131$; Estancia Limonao: $n=44 ;$ La Manea: n=125; Cañadón Los Chivos 1: n=11 (see geographic distribution of these localities in Figure 2). 3.2, Detailed taxonomic composition present in the different fish-bearing layers ( $L 1$ to $L 7$ from the top to the base of the sequence) of the La Manea locality: Layer 1: $n=9$; layer 3: $n=18$; layer 4: $n=11$; layer 5: $n=8$; layer 6: $n=11$; layer 7: $n=7$.

al., 2013). Thus, more data is needed to establish the exact age within the Upper Jurassic.

Apart from the Almada fish fauna, vertebrate remains from other parts of the Cañadón Calcáreo Formation include a new species of crocodile from the fluvial beds above the fish layers at Puesto Almada (Pol et al., 2011), the sauropod dinosaurs Tehuelchesaurus (Rich et al., 1999; Carballido et al., 2011), Brachytrachelopan (Rauhut et al., 2005) and an undeterminate brachiosaurid (Rauhut, 2006a), as well as undescribed remains of theropod dinosaurs and temnospondyl amphibians (OWMR pers. obs.). Fragmentary turtle remains reported from this formation by Rauhut (2006a) and described by Sterli (2009) are now considered to come from the Lower Cretaceous Los Adobes Formation (OWMR and Diego Pol, pers. obs.).

The fishes mainly occur in the southern part of the outcrop area of the Cañadón Calcáreo Formation (Figure 1), which has a total of up to $60 \mathrm{~m}$ of lacustrine sediments at its base. Fish remains occur in various layers, but are especially abundant in a single layer (about $80 \mathrm{~cm}$ ) near the top of the lacustrine sequence.

This main fish-bearing stratum of the Cañadón Calcáreo Formation is found in at least seven localities (Figure 2): Puesto Almada (Estancia Farías), Punta Biotita (some $1000 \mathrm{~m}$ west of Puesto Almada), Estancia Limonao, two localities at the entrance of the Cañadón Los Chivos, Cañadón Las Minas, and Sierra de la Manea. Most of these localities are placed on both sides of the Chubut River, up to $8 \mathrm{~km}$ distant from one another. Only in the most distant locality of La Manea, which is placed some $30 \mathrm{~km}$ away from Puesto Almada, several layers with abundant fish remains appear, intercalated with desiccation cracks.

Although these localities are distant from one another, they bear a remarkably uniform fish composition. All of the fish-bearing layers contain the teleost $\dagger$ Luisiella feruglioi (new combination after Sferco, 2011), the chondrostean †Condorlepis gen. nov., and a diverse array of dominantly teleost species (Figure 3). A predator-prey relationship between †Luisiella feruglioi and †Condorlepis gen. nov. is suggested by the occurrence of $†$ Condorlepis specimens with teleost remains in their digestive system and the frequent association of both taxa.

†Luisiella feruglioi is the principal component of the fish fauna, representing more than the $85 \%$ of the fishes; †Condorlepis gen. nov. is represented by less than $10 \%$. Although this is the generalized case, in the Estancia Limonao, the specimens of †Condorlepis gen. nov. make up to $25 \%$ of the total number of fishes. Other actinopterigyans (indeterminate, though certainly not 
referable to †Luisiella or †Condorlepis) are rare and appear exclusively in Sierra de la Manea and Estancia Limonao (Figure 3). In Sierra de la Manea, †Luisiella feruglioi represents up to $80 \%$ and $\dagger$ Condorlepis gen. nov. $10-15 \%$ of the total fish fauna, with this genus accounting for up to $50 \%$ of the fish fauna in some layers in this locality (Figure 3.2).

The remarkably uniform fish composition found in all the studied localities of the Cañadón Calcáreo Formation suggests that a single lake or a series of smaller interconnected lakes were present. Additionally, the absence of fossil plants and tetrapods supports the hypothesis of a single large lake. The main mass occurrence of fishes in a single, tuffacious layer indicates a mass-mortality event, possibly triggered by volcanic activity.

\section{SYSTEMATIC PALAEONTOLOGY}

$$
\begin{aligned}
& \text { Subclass ACTINOPTERYGII Cope, } 1887 \\
& \text { Infraclass ACTINOPTERI Cope, } 1871 \\
& \text { Series CHONDROSTEI Müller, } 1844 \\
& \text { Family †COCCOLEPIDIDAE Berg, } 1940
\end{aligned}
$$

Diagnosis (emended from Berg, 1940 and Hilton et al., 2004). Chondrostean fishes with the following combination of characters: dermal bones of the skull roof and maxilla ornamented with small and regularly distributed tubercles or sharply pointed denticles; anterior abdominal scales are of the amioid-type; nasal bones contact only anteriorly, posteriorly separated by postrostral; small postrostral bone not reaching the rostral; maxilla with large postorbital plate; supracleithrum is as large or larger than cleithrum.

Included genera. †Coccolepis Agassiz, 1843, from the Late Jurassic of Solnhofen, Germany; †Sunolepis Liu, 1957, from the Late Jurassic or Early Cretaceous of Yumen, Gansu Province, China; †Plesiococcolepis Wang, 1977, from the Early Jurassic of Lingling-Hengyang, Hunan Province, China; †lyalepis Sytchevskaya, 2006, from the Early to Middle Jurassic Cheremkhovskaya Formation of Baikal Region in Siberia; †Morrolepis Kirkland, 1998, from the Late Jurassic Morrison Formation, USA; †Condorlepis gen. nov., from the Late Jurassic (Oxfordian-Tithonian) Cañadón Calcáreo Formation, Chubut Province, Argentina.

Genus †COCCOLEPIS Agassiz, 1843

Emended diagnosis. Coccolepidid fish with the following combination of characters: dermal bones of the skull roof, scales, and fin rays ornamented with mostly regularly arranged sharply pointed, posteriorly directed denticles; lower jaw long and very slender; fringing fulcra present in pectoral and caudal fins only.

Type species. †Coccolepis bucklandi Agassiz, 1843, from the Late Jurassic of Solnhofen, Germany.

Other accepted species. †Coccolepis liassica Woodward, 1890, from the Early Jurassic (Sinemurian) of Dorset, England; †C. andrewsi Woodward and Sherborn, 1890, from the earliest Cretaceous Lower Purbeck Beds at Wiltshire, England; $† C$. australis Woodward, 1895, from the Late Jurassic (Tithonian) Talbragar Beds in Australia; †C. macroptera Traquair, 1911, from the Early Cretaceous of Bernissart, Belgium; $†$. aniscowitchi GorizdroKulczycka, 1926, from the Late Jurassic Kara-Tau, Kazakhstan; †C. woodwardi Waldman, 1971, from the Early Cretaceous of Koonwarra, Victoria, Australia.

\section{Genus †CONDORLEPIS gen. nov.}

Derivation of name. The new generic name is a combination of the name of Village of Cerro Cóndor, which is the small village closest to the type locality, and the Greek "lepis", a scale.

Diagnosis. As for the type and so far only known species.

Type species. †Oligopleurus groeberi Bordas, 1943

†Condorlepis groeberi (Bordas, 1943) n. comb.

Figure 4, Figure 5, Figure 6, Figure 7, Figure 8, Figure 9, Figure 10, Figure 11, Figure 12, Figure 13, Figure 14, Figure 15, Figure 16, Figure 17

1943 †Oligopleurus groeberi Bordas: Physis 19(53): 317, pl. 2.

1978 +Coccolepis groeberi Bocchino: 310-317, fig. 2, pl. 2.

1987 †Coccolepis groeberi Cione and Pereira: 289-290, pl. 2, pl. 5: fig. B,

Lectotype. MACN 14434, moderately well-preserved, almost complete specimen missing the posterior half of the caudal fin (Estimated TL 126 $\mathrm{mm}$; Figure 4.1).

Paralectotype. MACN 14433, incomplete specimen including a well-preserved caudal fin and almost complete anal fin (Figure 4.2).

Referred specimens. MACN 14432, 18551 (including 18630A, 18552 and 18553), 18561, 18562, 18575; MPEF-PV 1496-5A, 1556-6, 1731, 1732, 1733, 1766, 1767, 3958, 10504-507.

Diagnosis. Coccolepidid fish with the following combination of characters: dermal bones of the skull roof, maxilla and scales, but not fin rays, ornamented with small and irregularly distributed tuber- 


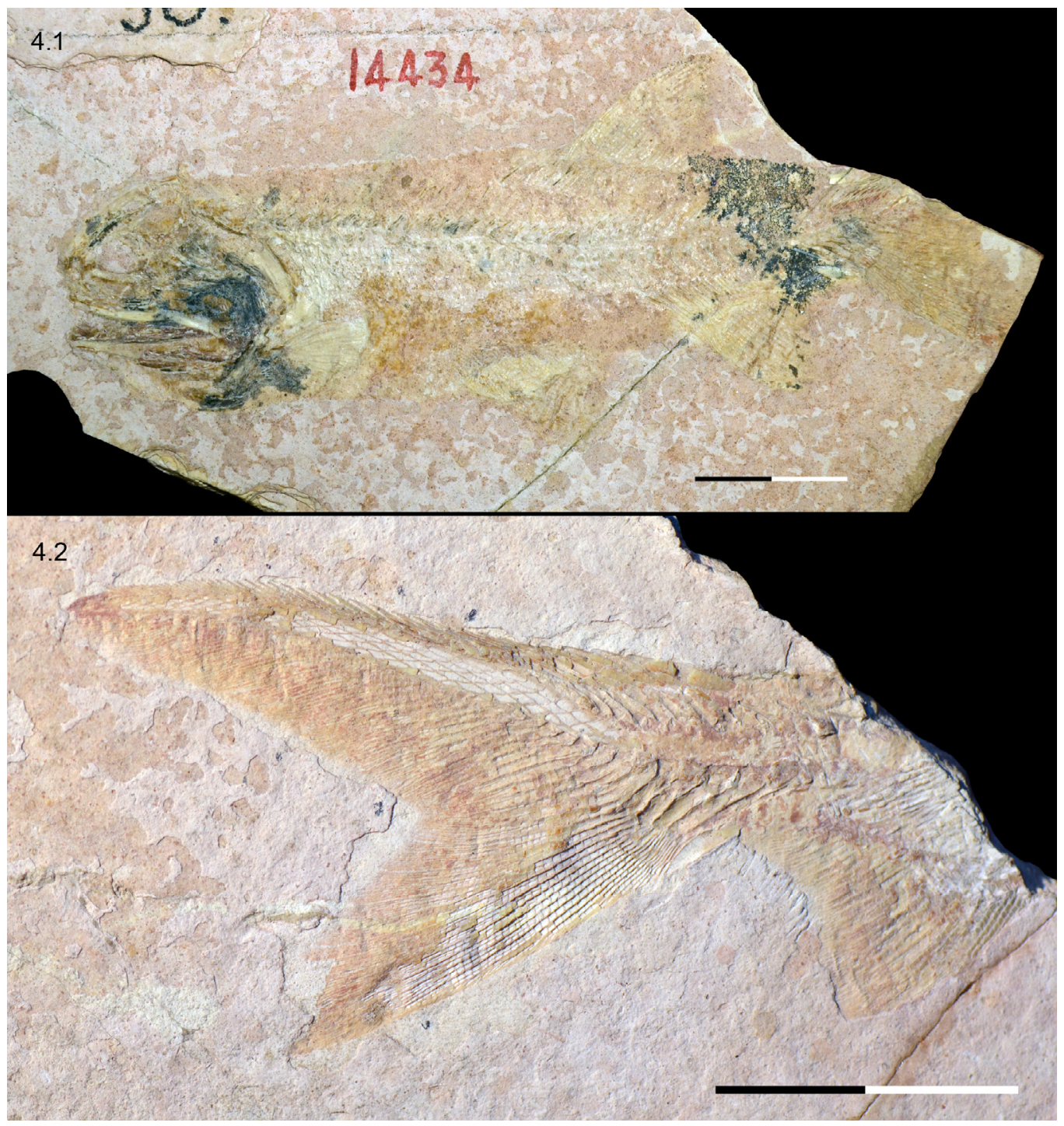

FIGURE 4. Photographs of two type specimens of †Condorlepis groeberi (Bordas, 1943) n. comb. 4.1, MACN 14434 (lectotypie); 4.2, MACN 14433 (paralectotype). Scale bars equals $2 \mathrm{~cm}$.

cles; small rostral; lower jaw long and slender, but robust; suboperculum, branchiostegal and gular plates ornamented with low concentric striae; gular plate small and rounded, traversed by a sensory canal; supracleithrum longer than cleithrum; small, oval postcleithrum; fringing fulcra present in caudal fin only.

Type locality. According to Bordas (1943: 316) the type specimens were found in "Valle medio del Río Chubut, en el lote 24 sección li, cerca de la casa de Marcos Almada, aguas arriba del Paso de los Indios (Territorio del Chubut)" [central Río Chubut valley, in the lote 24 section li, close to the house of Marcos Almada, upstream from the Paso de los Indios (Territory of the Chubut)]. The house of Marcos Almada is known as Puesto Almada, Estancia
El Torito, and is located some $20 \mathrm{~km}$ north of the village of Cerro Cóndor, at the Ruta Provincial $\mathrm{N}^{\circ}$ 12 in the valley of the Chubut River (Figure 2).

Type horizon. "Estratos de Almada," basal lacustrine section of the Cañadón Calcáreo Formation (Late Jurassic: Oxfordian-Tithonian).

\section{ANATOMICAL DESCRIPTION}

Like other chondrostean fishes, †Condorlepis groeberi (Bordas, 1943) n. comb. is a very slender fish, with the peculiarity that the body is deepest at the relatively large head and gradually decreases in depth posteriorly, ending in a strongly heterocercal tail with a very long body lobe that culminates in a short cercus-like extension (Figure 4, Figure 5). 


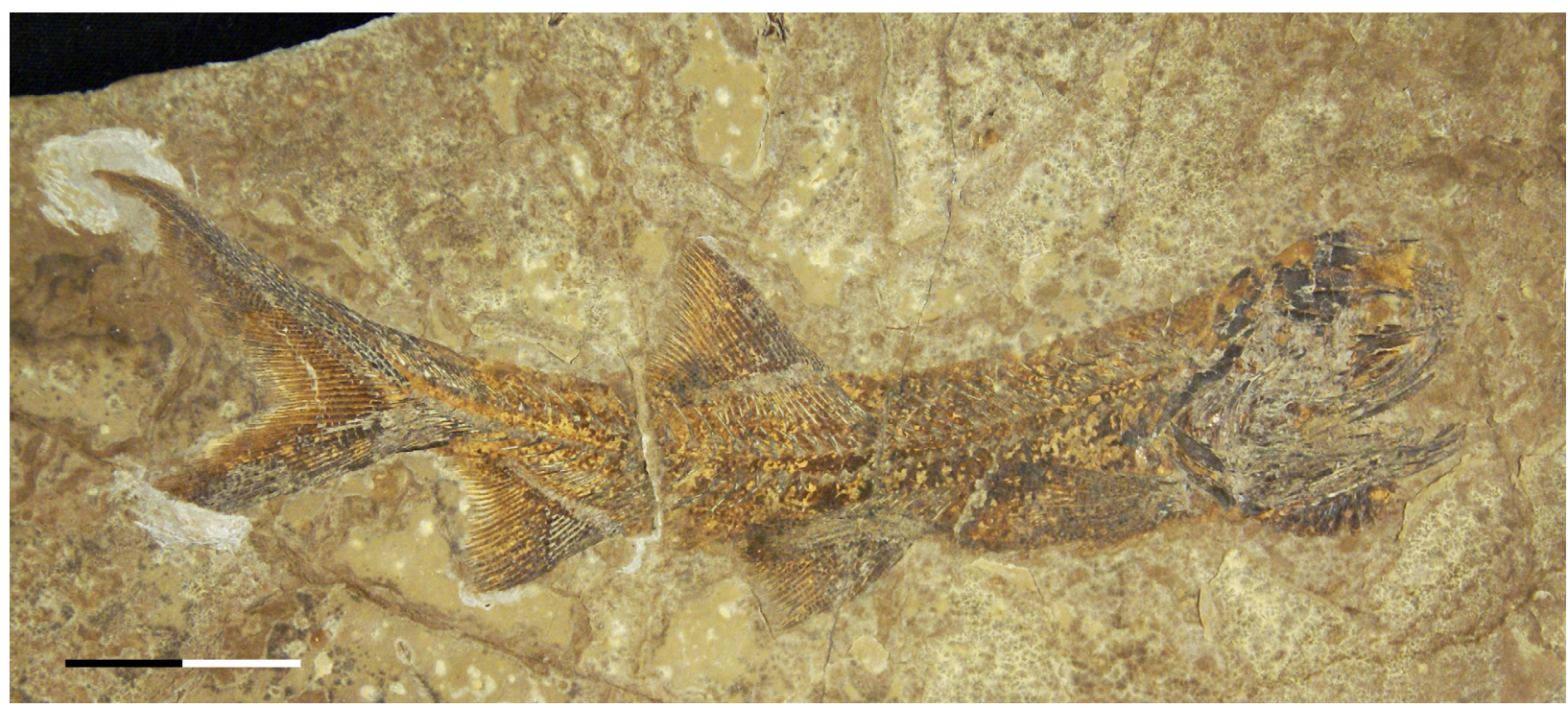

FIGURE 5. Photograph of the specimen MPEF-PV 1731A of $†$ Condorlepis groeberi. Scale bar equals $2 \mathrm{~cm}$.

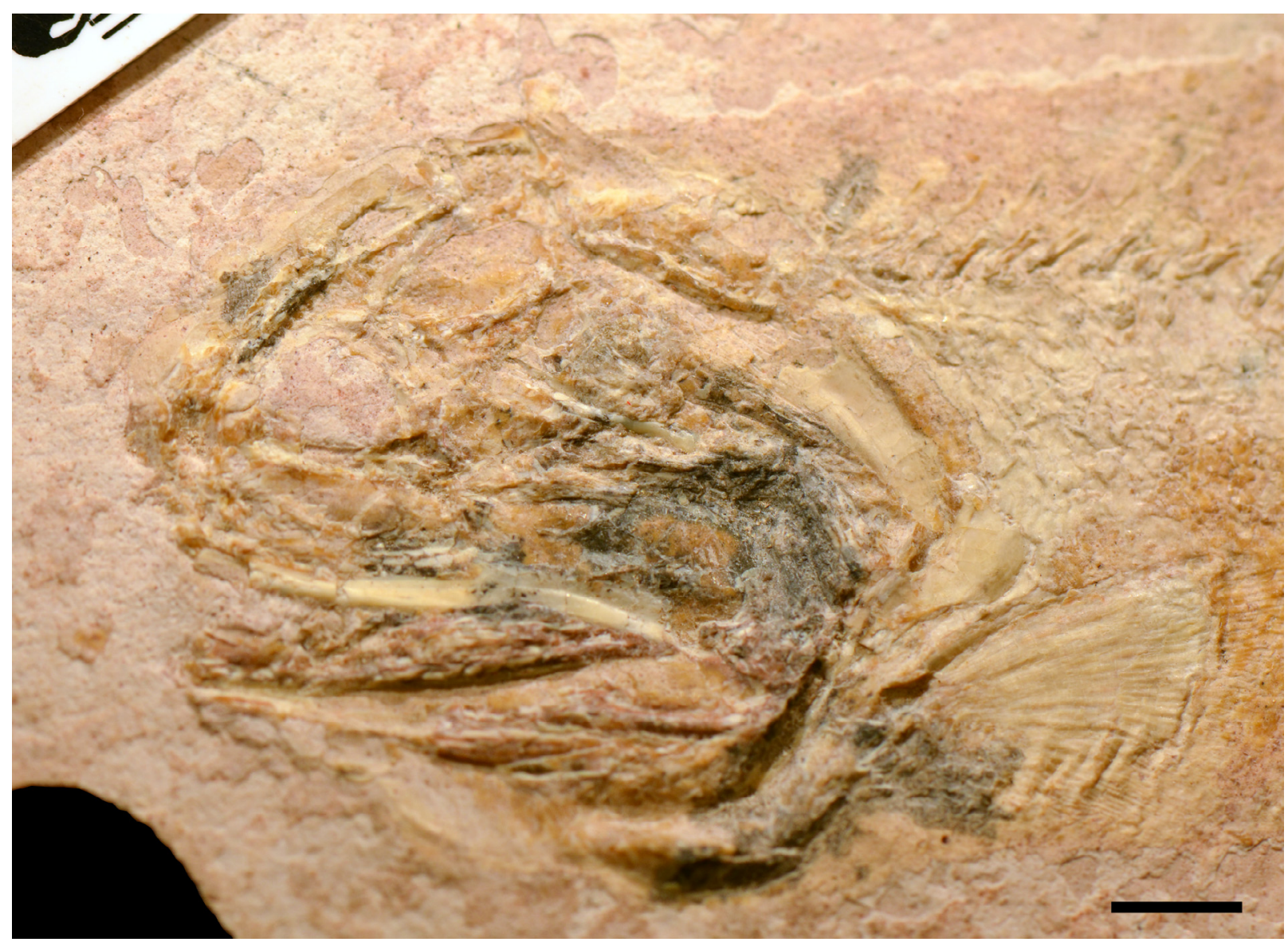

FIGURE 6. Photograph of the skull of †Condorlepis groeberi in MACN 14434 (lectotype). Scale bar equals $5 \mathrm{~mm}$. 


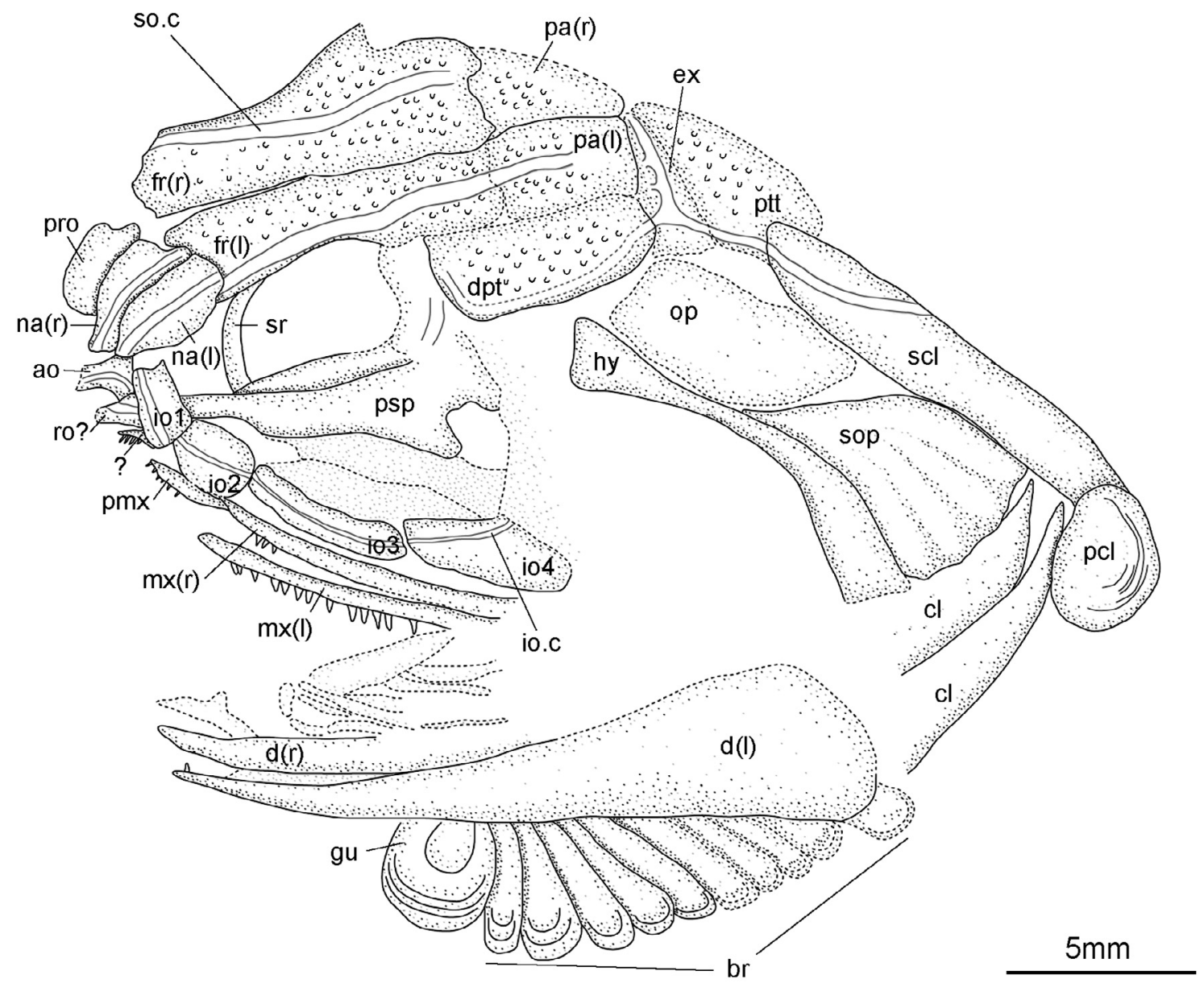

FIGURE 7. Line drawing of the skull of †Condorlepis groeberi in MPEF-PV 1731B.

The total length (TL) of the complete specimens (MPEF-PV 1731, 1732, 1733, 3958, and 1767) varies between 85 and $116 \mathrm{~mm}$. The total length of the lectotype (MACN 14434) is about $126 \mathrm{~mm}$, estimated according to the ratio of the head length relative to the total length calculated for the complete specimens (Table 1). The largest specimen is also incompletely preserved and its total length is estimated as $185 \mathrm{~mm}$ (MPEF-PV 1766). The head is longer than deep (on average $\mathrm{HD} / \mathrm{HL}=0,81$; Table 1) with the orbit placed in the anterior half of the skull, the snout is blunt and the suspensorium is very inclined (Figure 6). The length of the head measured from the anterior border of the nasals to the posterior border of the operculum at a level right before the articulation of the supracleithrum and the cleithrum is on average $23 \%$ of the $T L$ (range: $21-24 \%, n=6$ ). The maximum depth of the postcranium is immediately behind the pectoral girdle and represents around 17\% of TL (range: 17-
$18 \%, n=5)$. The pelvic fins are placed at $39 \%$ of $T L$ (range: $35-43, n=6$ ), and the dorsal and anal fins are placed at $44 \%$ of TL (range: $42-47 \%, n=6$ ) and $58 \%$ of TL (range: $54-65, n=6$ ), respectively. The ranges of variation for these proportions are not related to the size of the specimens (Table 1).

The preservation of the skull is generally rather poor and most of the bones are crushed. In many cases the real borders of the bones are incompletely preserved and their outline has been reconstructed. Despite such difficulties, besides the general gross morphology, the specimens have revealed several anatomical details and features that are systematically important.

Snout and skull roof. The snout is formed by a small rostral, which is traversed by the ethmoidal commissure, a relatively small anamestic postrostral and paired nasals (Figure 7, Figure 8, Figure 9 ). The shape of the nasals resembles an inverted bottle with a broad and largest dorsal portion and a 

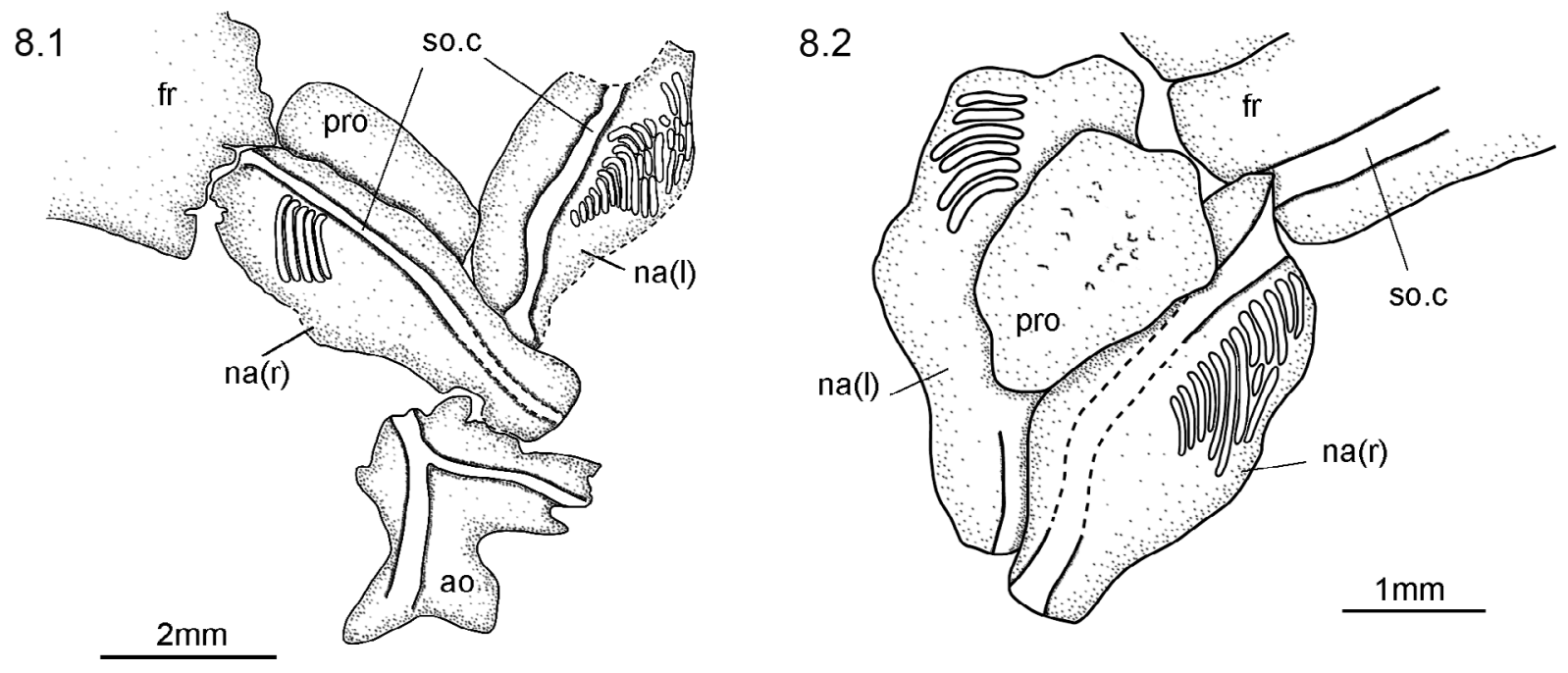

FIGURE 8. Snout bones in †Condorlepis groeberi. 8.1, Line drawing of the slightly disarticulated postrostral, nasal and antorbital bones in MPEF-PV 3958. 8.2 Line drawing of the articulated postrostral and nasal bones in MPEF-PV $1732 \mathrm{~B}$.

narrow ventral neck, and the bone is traversed by the anterior portion of the supraorbital sensory canal (Figure 8). Lateral to the path of the canal, the dorsal portion of the nasal is ornamented with relatively broad parallel ridges. The two nasals are separated dorsally, but they meet at the midline along the ventral, narrow portion. Between the dorsal portions of the nasals, a median anamestic bone is sutured to the anterior border of the frontals (Figure 8.2). Although this bone does not reach the rostral ventrally, it is probably homologous to the postrostral bone of †Birgeria and other basal actinopterygians.

The skull roof has a perfectly rounded profile (MACN 14434; Figure 6) and is oriented in anteroventral to postero-dorsal direction. The frontals are the largest bones in the roof of the skull (Figure 6, Figure 7, Figure 9). They do not extend beyond the anterior rim of the orbit and consist of approximately equally large orbital and postorbital portions. The two frontals meet at the dorsal midline in an almost straight suture (MPEF-PV 1731, 1732). Posterior to the frontals, the two parietals are approximately quadrangular. The fronto-parietal and the inter-parietal sutures are almost straight. The dermopterotics are very large, sutured to the lateral border of the parietals and extending forwards suturing to the postorbital portion of the frontal and reaching close to the orbital margin. There is a single pair of narrow, laterally elongated extrascapulars suturing the parietals and dermopterotics posteriorly. The extrascapulars are widest at their lateral borders and narrow towards the midline. Posterior to the extrascapulars there is a single pair of large posttemporal bones. Frontals, parietals, dermopterotics, extrascapulars, and posttemporals are ornamented with densely and irregularly arranged tubercles.

The supraorbital sensory canal runs from the nasals posteriorly almost straight and parallel to the inter-frontal suture, and ends in the anterior portion of the parietal (Figure 7, Figure 9). The temporal canal runs through the latero-ventral margins of the posttemporal, extrascapular and dermopterotic bones and turns upwards rather abruptly at the anterior margin of the dermopterotic to meet the infraorbital canal in the dermosphenotic bone. The extrascapular bones are further traversed by the supratemporal commissure.

Circumborbital bones. Three slender sclerotic bones are preserved in MPEF-PV 3958 (Figure 9), but the total number was probably four. Starting at the ethmoidal commissure, the infraorbital sensory canal is contained in the antorbital, five infraorbital bones and the dermosphenotic. The antorbital bone, which is best preserved in MPEF-PV 3958 and 10504, is Y-shaped and carries the junction between the ethmoidal commissure and the supraorbital and infraorbital canals (Figures 7, Figure 8, Figure 9). The first infraorbital bone is small and subrectangular, longer than deep, and is located at the anteroventral corner of the orbit. Two other infraorbitals form the ventral margin of the orbit, these two infraorbitals are longitudinally elongated, the first of them being short, a little longer than deep, but the second is long and a little deeper 


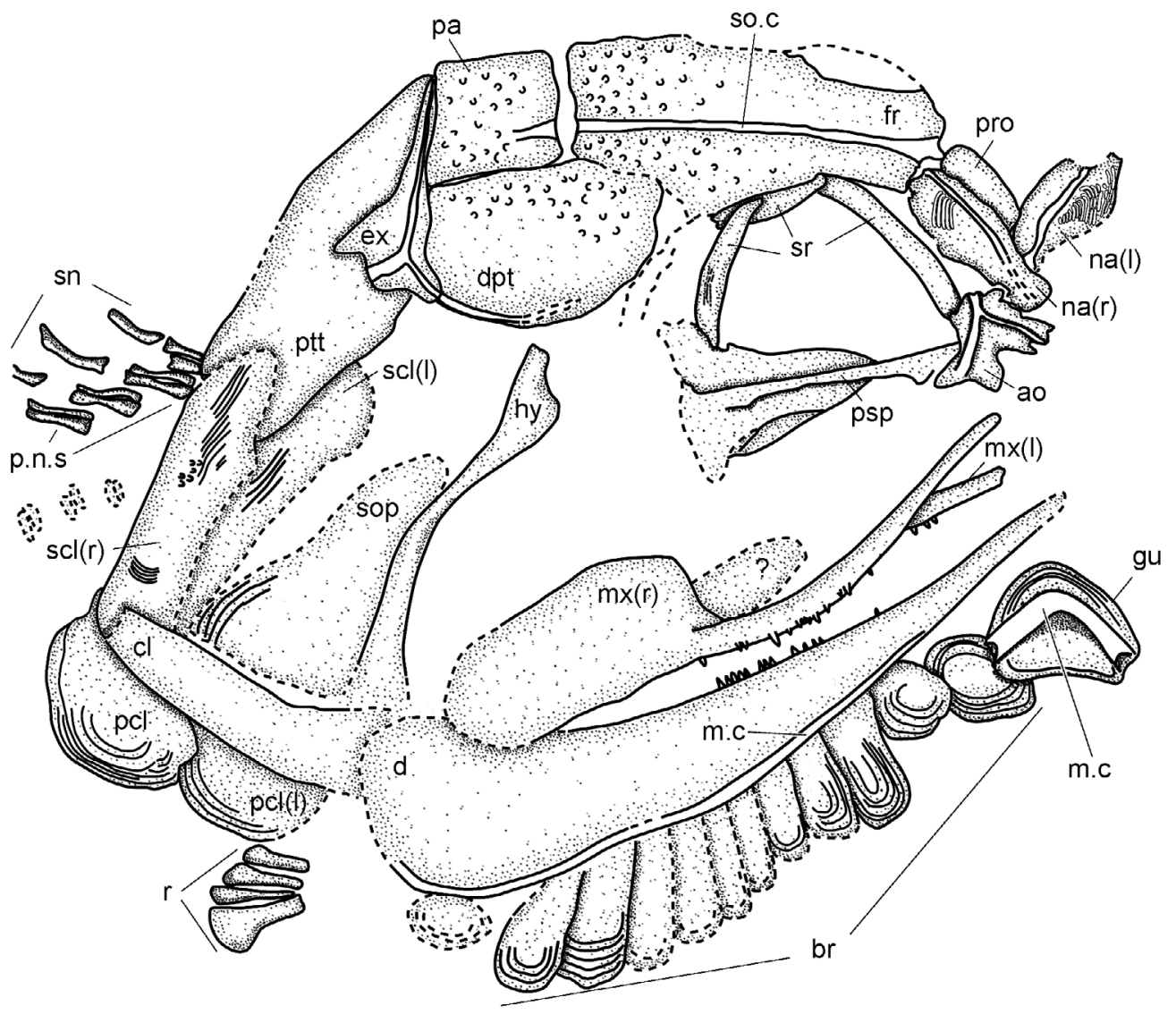

$\underline{2 \mathrm{~mm}}$

FIGURE 9. Line drawing of the skull of †Condorlepis groeberi in MPEF-PV 3958.

posteriorly. The fourth infraorbital is located at the posteroventral corner of the orbit, it extends into the dorsal margin of the orbit and is expanded posteriorly (the dorsal portion of this bone is not preserved in MPEF-PV 1731). The posterior border of the orbit is completed by one small and tubular infraorbital bone and the dermosphenotic, which is also small and tubular, and is almost dorsoventrally oriented. Supraorbital bones are absent.

Jaws. The upper jaw is formed by very small premaxillae and large maxillae (Figure 6, Figure 9, Figure 10). The premaxillae are generally not preserved, but MPEF-PV 1731 preserves a small and very slender premaxilla articulating with the right maxilla (Figure 10.1). This small premaxilla is approximately five times longer than deep and bears small conical teeth. The maxillae have a very thin infraorbital portion and a widely expanded postorbital portion. The infraorbital portion tapers anteriorly and has posteriorly divergent slightly convex ventral and slightly concave dorsal margins. The postorbital portion of the maxilla is incompletely preserved in the studied specimens, but it can be reconstructed. The dorsal portion is best preserved in the disarticulated maxilla in MPEF-PV 1496-5A (Figure 10.2). Behind the orbit, the dorsal border of the maxilla bends abruptly upwards, forming a rectangular postorbital plate, which is almost 3 times higher than the maxillary infraorbital portion at its maximal height. The dorsal border is convex, curving in posteroventral direction, and the posterior border is straight and inclined posteriorly. The anterior and posterior borders divert upwards, with the posterior border more posteriorly inclined than the anterior border. The ventral border of the postorbital portion is concave and, thus, the ventral border of the maxilla taken as a whole is sinuous, turning from convex to concave.

The lower jaw is poorly preserved in the studied specimens. A coronoid process of the neopterygian type is absent and the lateral surface is mainly made up by the large dentary (Figure 7, Figure 9). The mandibular sensory canal runs very 


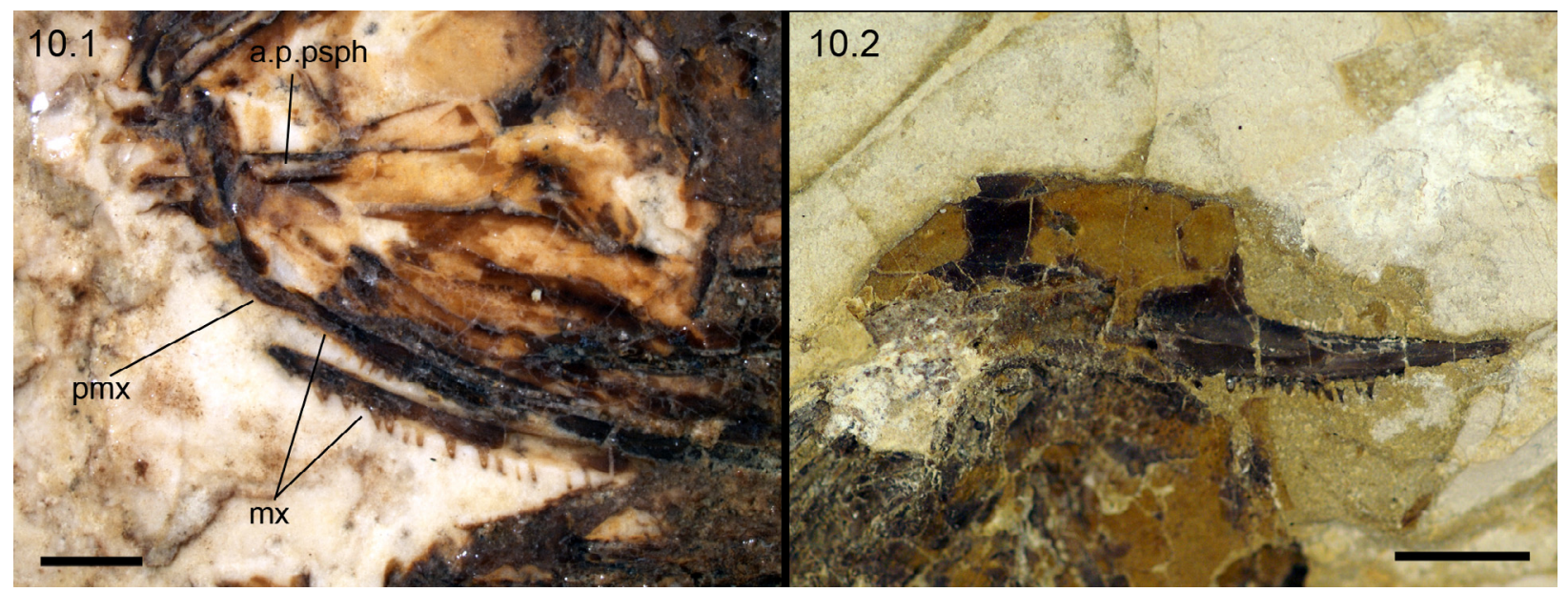

FIGURE 10. Upper jaw of †Condorlepis groeberi. 10.1, Detailed photograph of MPEF-PV 1731B showing the premaxilla; the anterior process of the parasphenoid is also well shown in this picture; scale bar equals $2 \mathrm{~mm}$. 10.2, Disarticulated maxilla in MPEF-PV 1496-5A, scale bar equals $5 \mathrm{~mm}$.

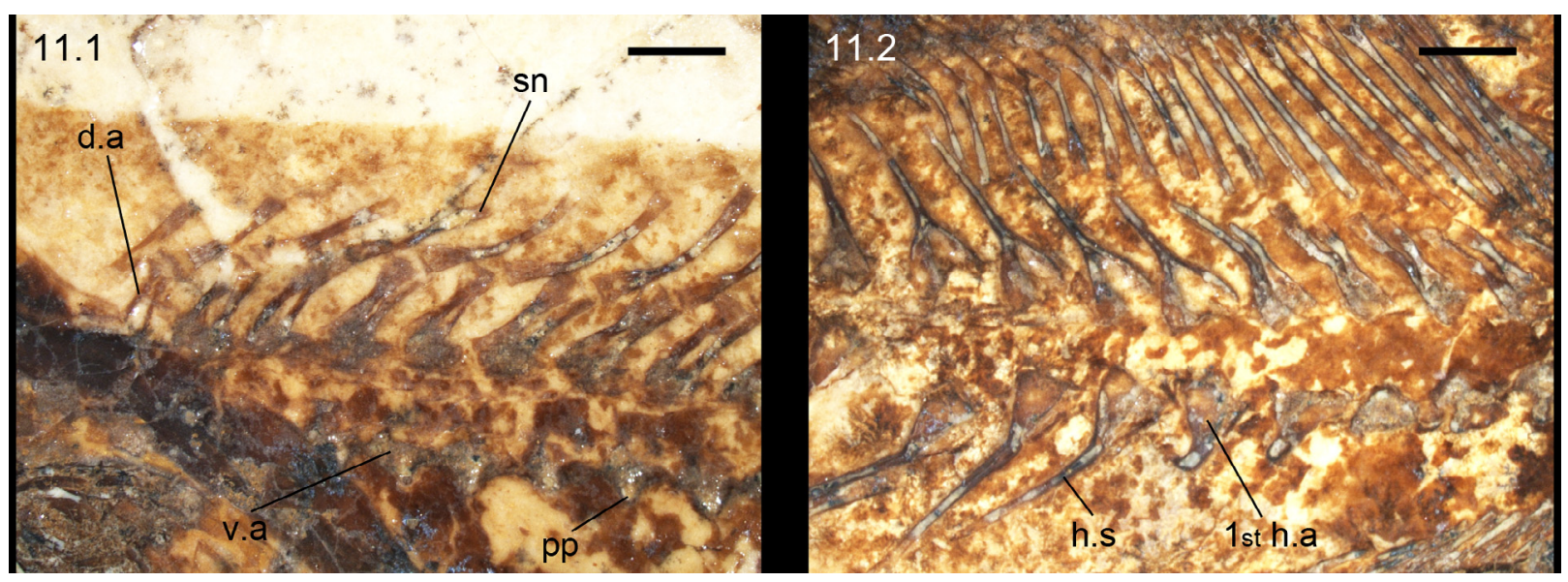

FIGURE 11. Vertebral column of †Condorlepis groeberi. Detailed photographs of the specimen MPEF-PV 1731B: 11.1 , anterior portion of the abdominal region, directly behind the skull; 11.2 , central portion of the vertebral column showing the transitional morphologies between the abdominal and caudal regions.

close to the ventral margin of the bone and exits the dentary before the symphysis. The dentary and maxilla bear two rows of conical teeth: a lateral row of very minute conical teeth and a medial row of larger and sharp conical teeth. Other bones or details of the lower jaw are not discernable.

Palatoquadrate and parasphenoid. Of the palatoquadrate only the very elongated and sharply pointed dermopalatine bones are observable. The anterior portion of the dermopalatines resembles the anterior portion of the maxillae very closely and bears a single row of conical teeth, which are similar to the large medial maxillary teeth.

The parasphenoid is well preserved in several specimens. Like in other chondrosteans, the orbital portion of the parasphenoid is broad and presents a distinct median anterior process and large ascending processes (Figure 7, Figure 9, Figure 10.1).

Opercular bones and hyoid arch. The preoperculum is very narrow and inclined, resembling the shape and position of the underlying hyomandibula, but narrowing posteroventrally (Figure 6). The operculum is quadrangular in shape and notably smaller than the suboperculum (Figure 6, Figure 7). The suboperculum is fan-shaped with an undulated surface and has a broad anterodorsal process.

A series of numerous branchiostegal rays is incompletely preserved in the studied specimens, although almost complete series, with 11 and 12 plates preserved in MPEF-PV 1731 and 3958 (Fig- 


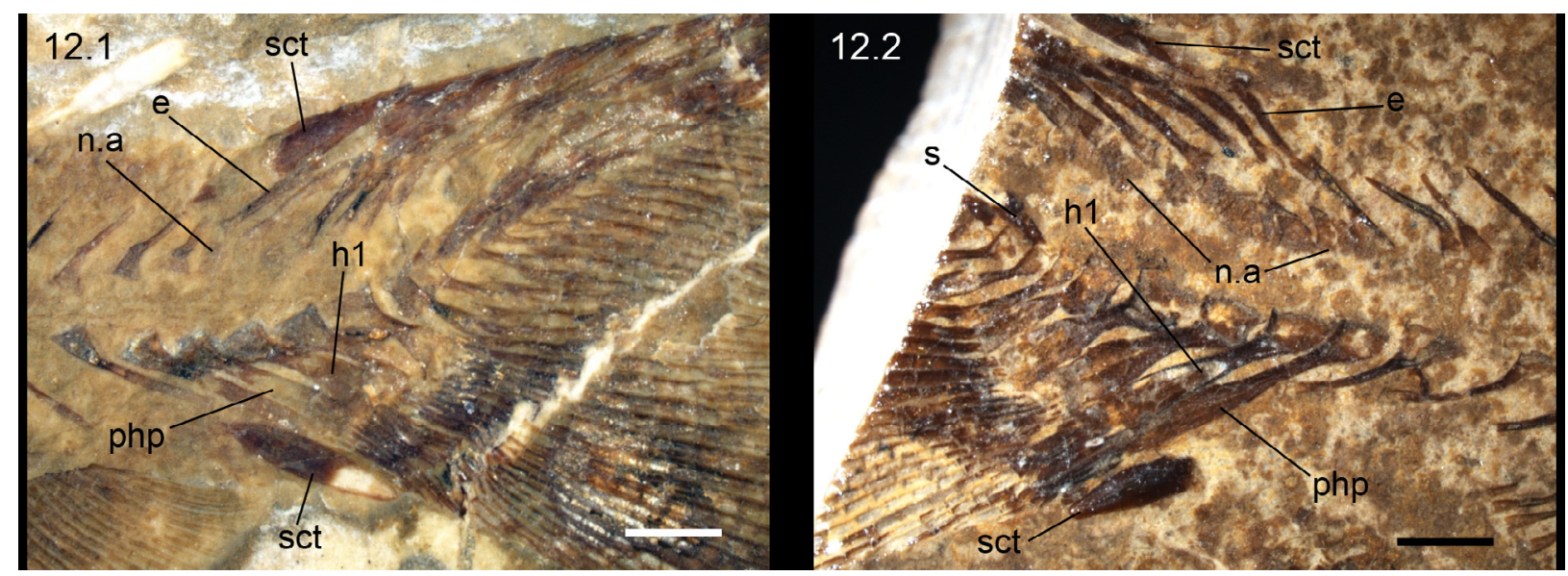

FIGURE 12. Caudal skeleton of $†$ Condorlepis groeberi. 12.1, Photograph of MPEF-PV 1732B; 12.2, photograph of MPEF-PV 3958A. Scale bars equals $2 \mathrm{~mm}$.

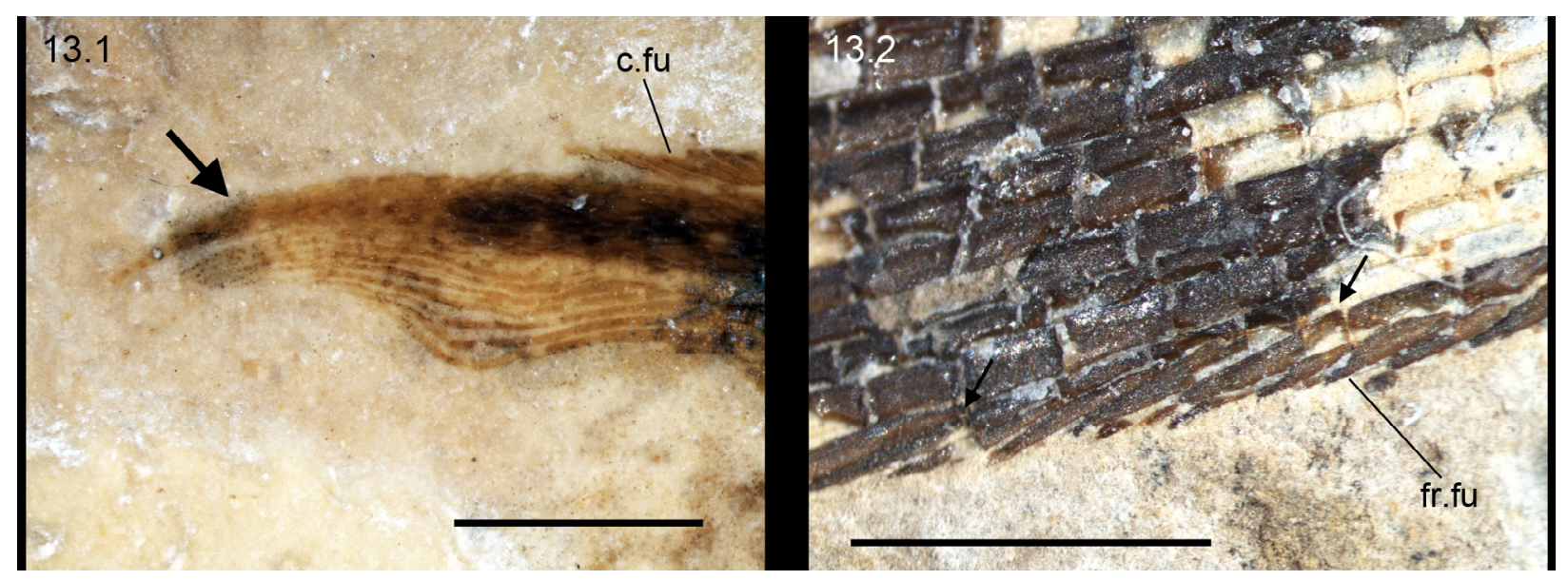

FIGURE 13. Detailed features of the caudal skeleton of †Condorlepis groeberi. 13.1, Photograph of MPEF-PV 1731B showing the exquisitely preserved small cercus-like extension of the body lobe, which is indicated by the black arrow; 13.2, detailed photograph of the ventral margin of the caudal fin in MPEF-PV 3958B showing the distal segments of two marginal fin rays intercalating between the fringing fulcra (black arrows). Scale bars equals $2 \mathrm{~mm}$.

ure 7, Figure 9). The total number of branchiostegals remains unknown. Each branchiostegal is plate-like and ornamented with a central shallow dome and concentric ridges. Anterior to the series of branchiostegals there is a single gular plate, which is very small, shorter than broad, with an almost straight posterior border (Figure 9). It is also ornamented with concentric ridges and it is transversally traversed by the mandibular sensory canals. The mandibular sensory canal from one side enters the gular plate from the dentary, runs into a gular commissure, and exits to the dentary on the other side (MPEF-PV 3598).

Among the elements of the hyoid arch, only the hyomandibula is visible. Like in †Birgeria, the hyomandibula consists of laterally compressed dorsal, almost horizontal shank, and a ventral, posteroventrally inclined shank (Figure 7, Figure 9). The dorsal shank is c. 1.3 times longer than the ventral shank. The generally rod-like hyomandibula is narrower in the middle, expanding both proximally and distally, and the transition between the dorsal and ventral shanks is very gradual. There is no opercular process or foramen for the truncus hyoideomandibularis.

Vertebral column and caudal fin. Only dorsal and ventral arcual elements are ossified in the vertebral column of †Condorlepis, and the notochord is persistent (Figure 4, Figure 5, Figure 6, Figure 11). There are $\sim 34-35$ preural vertebrae, including 21- 


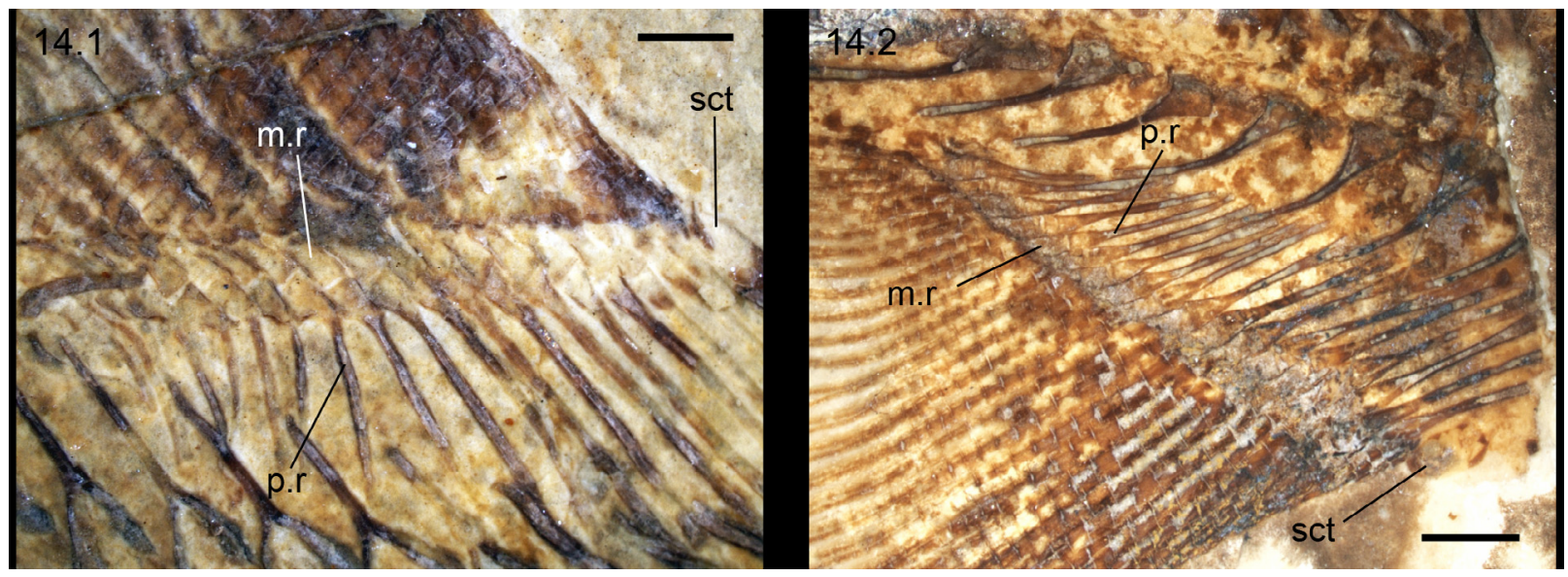

FIGURE 14. Dorsal and anal fins of †Condorlepis groeberi. 14.1, dorsal fin support in MPEF-PV 10506 showing separated proximal and middle radials; 13.2, anal fin support in MPEF-PV 1731B. Scale bars equals $2 \mathrm{~mm}$.

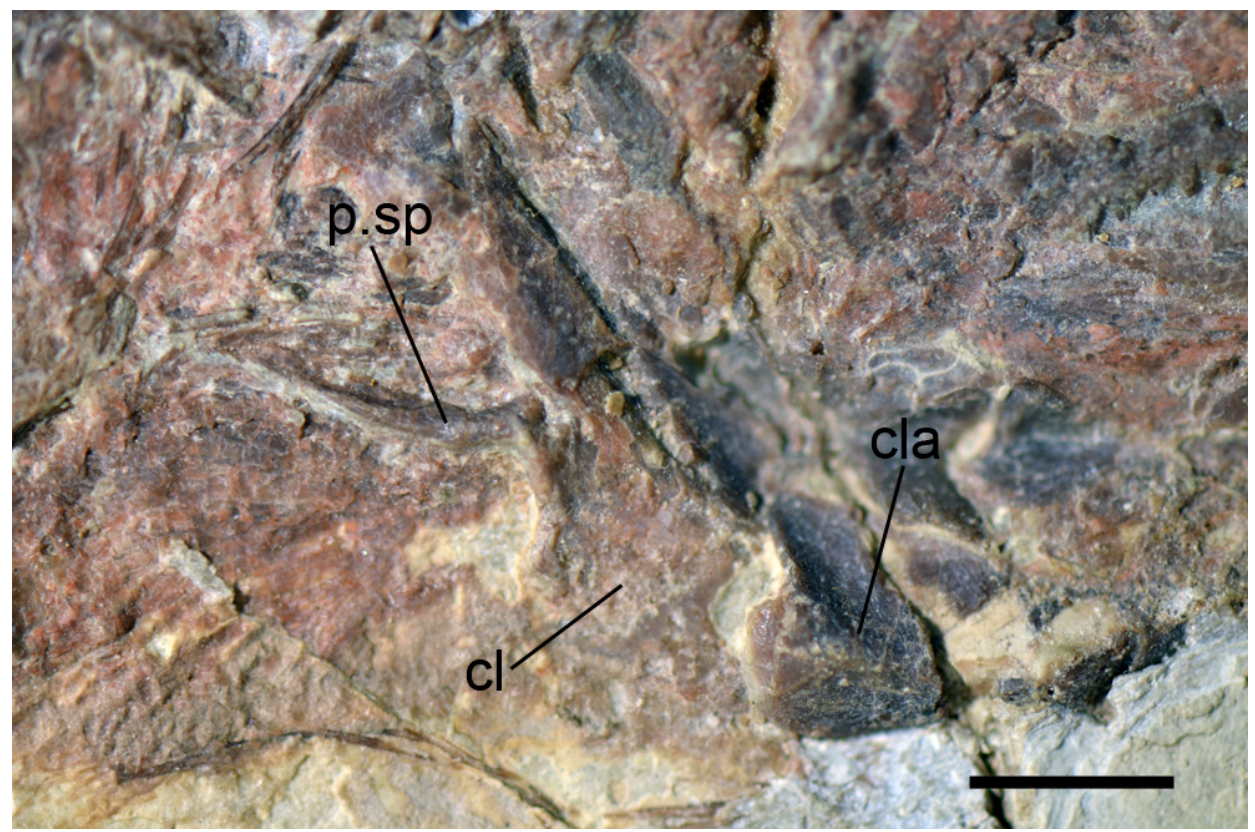

FIGURE 15. Photograph of †Condorlepis groeberi (MPEF-PV 1766) showing the pectoral spine. Scale bar equals 5 $\mathrm{mm}$.

23 abdominal vertebrae (Table 1). It was not possible to identify a parhypural with certainty. Therefore, our criterion to distinguish between ural and preural vertebrae is as follows: we identify the last preural vertebra as the vertebra with a complete neural arch and spine and the first enlarged and laterally compressed haemal spine.

In the abdominal region of + Condorlepis, the arcual ossifications consist mainly of separate ventral and dorsal arcocentra (Figure 11.1). Although ribs are not ossified, each ventral arcocentrum forms a short, but distinct parapophysis. The dorsal arcual ossifications are high and laterally compressed, constricted in the middle and expanded both dorsally and ventrally. The ventral portion of these basidorsal ossifications clearly corresponds to the neural arches, and we interpret the dorsal portion as paired neural spines. All of the abdominal neural spines are paired in MACN 18630 and MPEF-PV 1731 (Figure 11.2), but the condition is variable and the neural spine is unpaired and relatively short in the last abdominal vertebra in MPEFPV 3958, and in MPEF-PV 1733 and 1556-6 the neural spines of the two first caudal vertebrae are 


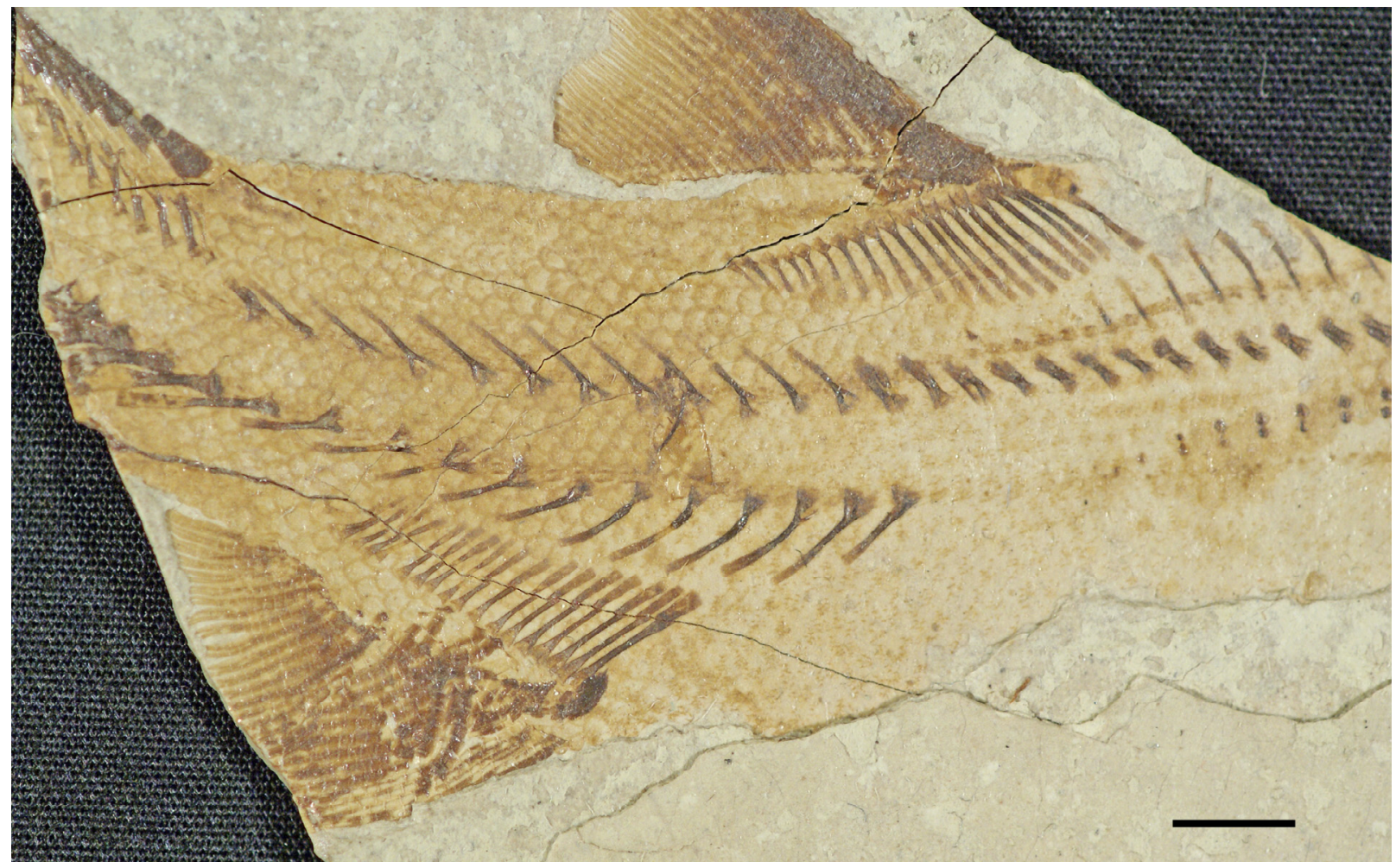

FIGURE 16. Body squamation in †Condorlepis groeberi (MPEF-PV 1556-6). Scale bar equals $5 \mathrm{~mm}$.

paired. The first haemal arch is small and has no haemal spine (Figure 11.2).

The caudal vertebrae are also only formed by arcual ossifications consisting of neural and haemal arches and spines. These neural spines are mostly unpaired, but one or two neural spines in the caudal peduncle might be paired (MPEF-PV 1731, 1733, 3958; Figure 12.2). Nine neural ural arches and 11 epurals are ossified in the ural region in MPEF-PV 1731. We interpret these latter elements as true epurals (i.e., detached neural spines) sensu to Schultze and Arratia (1989) because they are directly associated with the neural arches and no neural spine is ossified in the ural region (Figure 12). The ural skeleton is completed with numerous enlarged and laterally compressed hypurals. Twelve hypurals are visible in most of the specimens, but the exact number of hypurals is unknown because the most posterior elements are hidden below the scales of the body lobe.

There is a complete series of 14-18 rod-like supraneurals (Table 1; Figure 4, Figure 5, Figure 6, Figure 11) between the skull and the dorsal fin. Up to two supraneurals might be located under the first dorsal pterygiophores, but this condition is variable and independent of the total number of supraneurals.
The caudal fin is heterocercal and ends in a short cercus-like extension of the body lobe, which extends beyond the last lepidotrichia and is covered with tiny scales (Figure 4.2, Figure 13.1). This structure is much shorter than the cercus (=caudal filament) of Scaphirhynchus species or Pseudoscaphirhynchus kaufmanni (Hilton et al., 2011) and the lateral line apparently ends right behind the last fin ray at the base of the cercus-like extension. The scale covering of the body lobe reaches up to the base of the eighth to sixth hypural. The caudal fin web is made up of c. 60 lepidotrichia and is deeply excavated, with the dorsal lobe longer than the ventral lobe, which forms a rounded distal end (Figure 4; MACN 14433, MPEF-PV 1767). All caudal fin rays are evenly segmented from their bases. The following features concerning the pattern of caudal fin rays are best preserved in MPEF-PV 1731 and, thus, although the pattern is the same in all of the studied specimens, precise numbers are based on this specimen only. The first ventral caudal fin ray articulates with the parhypural and is very short and unbranched (Figure 12). The following eight rays gradually increase in length, forming the ventral margin of the fin and are also unbranched. The ninth ray gives three branches, which also increase gradually in length and contrib- 


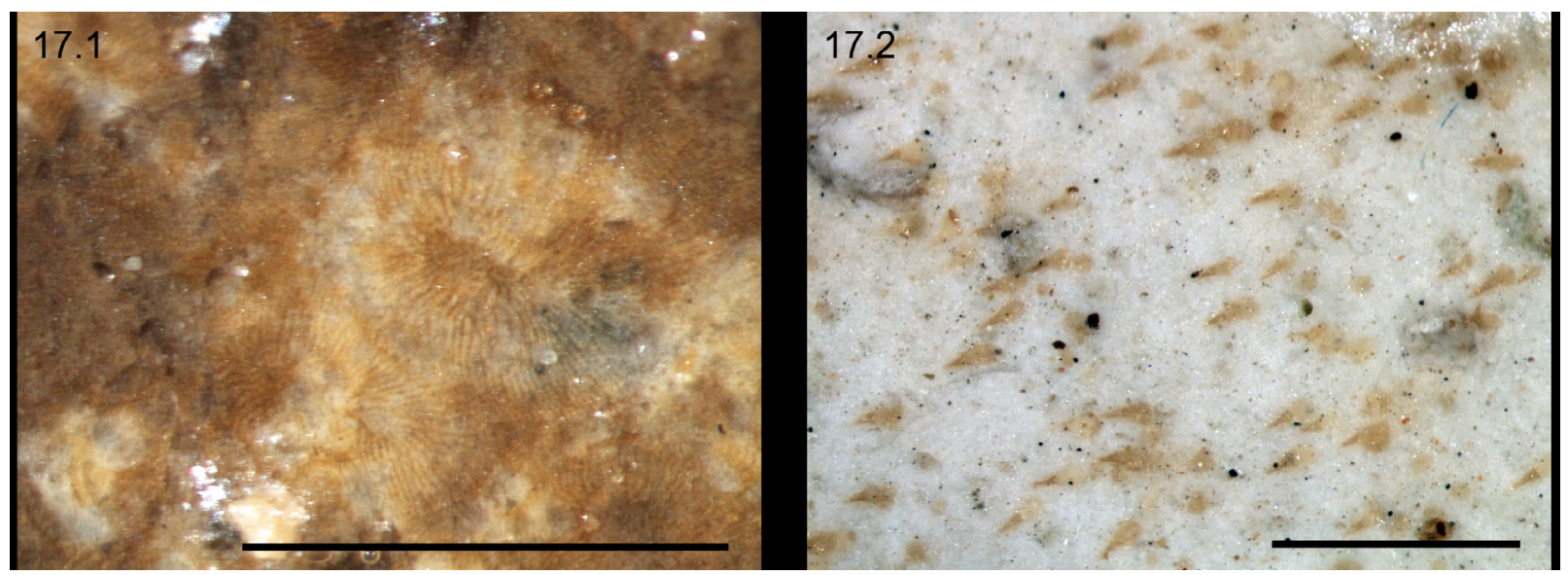

FIGURE 17. Detailed features of the scales in †Condorlepis groeberi. 17.1 Photograph of scales in MPEF-PV 1558 showing the ridges radiating from the growth center towards the borders of the scales; 17.2 photograph of scales in MPEF-PV 1556-6 showing the very fine and pointed denticles irregularly arranged. Scale bars equal $1 \mathrm{~mm}$.

ute to the ventral margin of the fin. The distal ends of these marginal fin rays intercalate with numerous slender fringing fulcra (Figure 13.2). One ventral caudal fulcrum precedes the ventral caudal fin rays that insert onto the body directly in front of the parhypural. In the dorsal lobe, one unpaired dorsal caudal fulcrum and c. 44 paired caudal fulcra formed the dorsal margin of the body lobe.

Dorsal and anal fins. The dorsal and anal fins are made up of numerous tightly packed lepidotrichia (Figure 4, Figure 5, Figure 14). Resembling the case of the ventral margin of the caudal fin, the most anterior dorsal and anal rays are unbranched and form the leading edge of these fins, with the first dorsal rays being very short and the few following rays increasing in height gradually. All dorsal and anal fin rays are evenly segmented from their bases. There are no fringing fulcra in the dorsal or anal fins.

There is a single series of radials supporting the dorsal and anal fin rays in the smaller specimens, but larger specimens (e.g., MPEF-PV 1731, $1733,3958,10506$, MACN 18630) have proximal and middle radials ossified separately (Figure 14). The total number of dorsal and anal pterygiophores varies between 19-21 and 18-21, respectively (Table 1). One elongated oval scute lays on the skin preceding the dorsal and anal fins.

Pectoral girdle. The pectoral girdle consists of a triangular supratemporal, a large, dorsoventrally elongated supracleithrum, a distinctly oval postcleithrum and a massive cleithrum and clavicle and is generally very similar to the pectoral girdle in other fossil chondrosteans (e.g., †Birgeria,
†Peipiaosteus, †Chondrosteus) (Figure 7, Figure 9 , Figure 15). The posttemporal is large and posteroventrally elongated, with a rounded posteroventral border. The supracleithrum has rounded anterodorsal and posteroventral borders, an almost straight anteroventral border and a convex posterodorsal border, and it is extremely long, the supracleithrum being longer than the cleithrum and notably longer than in other known chondrosteans. The lateral line runs through the anteroventral region of the posttemporal, enters the dorsal portion of the supracleithrum, and exits this bone at about half of its length. A small rounded postcleithrum, ornamented with concentric ridges, articulates at the distal end of the supracleithrum.

The dorsal portion of the cleithrum is inclined posteroventrally and tapers toward the distal end. Its ventral end is short and stout, with a posterior border that is straight and nearly vertical. The clavicle is massive and triangular. The pectoral fin consists of at least six elongated radials (MPEF-PV 1731), numerous fin rays, and a pectoral spine (Figure 15). The exact number of rays is unknown, but all rays are evenly segmented from their bases. There are no fringing fulcra in this fin.

Pelvic fins. Like in other chondrosteans, the pelvic fins are of the primitive kind, with c. 17 radials supporting the numerous and tightly packed fin rays (Figure 4, Figure 5). As in the other fins, the fin rays are evenly segmented from their bases, and the leading rays are unsegmented and gradually increase in height.

Squamation. The body of $†$ Condorlepis groeberi is covered with amioid-type scales (Figure 16, Figure 
TABLE 1.- Morphometric proportions measured on the six complete specimens. Abbreviations: TL, total length; HL, head length; BD, maximal depth of the body; PreV, length from the anterior border of the nasals to the origin of the ventral fins; PreD, length from the anterior border of the nasals to the origin of the dorsal fin; PreA, length from the anterior border of the nasals to the origin of the anal fin.

\begin{tabular}{lccccccc} 
Specimen & LT & HL/TL & HD/HL & BD/TL & PreV/TL & PreD/TL & PreA/TL \\
\hline MPEF-PV 1732 & 8,5 & 0,24 & 0,80 & 0,18 & 0,40 & 0,46 & 0,59 \\
MPEF-PV 1767 & 9,9 & 0,21 & 0,79 & 0,17 & 0,37 & 0,43 & 0,57 \\
MPEF-PV 1733 & 11 & 0,23 & 0,79 & 0,17 & 0,35 & 0,43 & 0,54 \\
MPEF-PV 3958 & 11,1 & 0,23 & 0,81 & & 0,38 & 0,42 & 0,58 \\
MPEF-PV 1731 & 11,6 & 0,23 & 0,84 & 0,17 & 0,43 & 0,47 & 0,65 \\
MACN 14434 & $12,6^{*}$ & $0,23^{*}$ & 0,85 & 0,25 & 0,41 & 0,52 & 0,65
\end{tabular}

17), as is the case in †Coccolepis bucklandi (Schultze, 1966). Also resembling this latter taxon, the scales in †Condorlepis bear numerous sharp, pointed denticles, but they are not arranged in rows like in the European species. The lateral line is enclosed in a well-ossified duct contained in normal body scales up to the base of the body lobe, where it is contained in small tubular scales and bends sharply following the bases of the caudal fin rays.

\section{DISCUSSION}

\section{Systematic position of †Condorlepis groeberi}

López-Arbarello et al. (2002) presented a phylogenetic hypothesis according to which †Condorlepis groeberi (Bordas, 1943) n. comb. and †Coccolepis bucklandi Agassiz, 1843 are sister groups and closely related to the Acipenseriformes within a monophyletic Chondrostei. Supporting these hypotheses, the detailed anatomical study of †Condorlepis groeberi led to the identification of several phylogenetically potentially important characters shared between these taxa. †Condorlepis groeberi and †Coccolepis bucklandi share a peculiar ornamentation of the dermal bones of the skull and the scales, the same kind of amioid-type scales, the small postrostral bone located between the dorsal halves of the nasals and a particularly large supracleithrum. The same or similar conditions have only been reported for other fishes referred to the family Coccolepididae (Woodward, 1890, 1891, 1895, 1915; Waldman, 1971; Kirkland, 1998).

Supporting the position of + Condorlepis groeberi as a stem taxon to the Acipenseriformes within a monophyletic Chondrostei, the Patagonian Jurassic species share the following features with the Acipenseriformes: parasphenoid with a median anterior process (Hilton et al., 2011: character 17); opercle smaller than suboperculum (Hilton et al., 2011: character 22); anterior margin of subopercle with anteriorly directed anterodorsal process (Hilton et al., 2011: character 27); single ventral caudal fulcrum (Hilton et al., 2011: character 52); presence of a pectoral fin spine (Hilton et al., 2011: character 53); and the lateral line bending upwards and continuing in the body lobe following the bases of the caudal fin rays. Additionally, †Condorlepis shares with †Birgeria and the Polyodontidae the very long and narrow supracleithrum, and with these fishes and several acipenserids the relative size of the supracleithrum, which is as large or larger than cleithrum. In †Condorlepis the antorbital bone is peculiarly shaped, resembling an inverted $Y$, as is the case with the most anterior lateral bone in the infraorbital series of Acipenser or †Peipiaosteus. The general shape of this Y-shaped bone in living acipenseriforms, its association to the sensory canals, and its developmental pattern (Jollie, 1980) indicates homology with the antorbital of other actinopterygians like Amia. This hypothesis of homology has been questioned by Hilton (2002). However, it is only the far anterior position of this Y-shaped bone and the impossibility to establish one-to-one correspondence of all the rostral canal elements in living acipenseriforms with bones of other actinopterygians, which challenges the hypothesis of its homology with the antorbital. A similar question of homology applies to the anterior bones in the infraorbital series of ginglymodians (López-Arbarello, 2012).

Despite sharing several characters with the acipenseriforms, †Condorlepis groeberi cannot be referred to the Acipenseriformes because it lacks the following synapomorphies of this clade: palatoquadrates with symphysis between pars autopalatina (Hilton et al., 2011: character 30; Grande and Bemis, 1996: character B1); premaxillary and max- 
illary bones absent (Hilton et al., 2011: character 32; Grande and Bemis, 1996: character B8).

\section{Comparisons with the Other Continental Fish Faunas from the Jurassic of Gondwana}

Most Jurassic freshwater fish assemblages of the Northern Hemisphere are rather poorly understood and distinct fish faunas have rarely been delimited (Kirkland, 1998; Chang and Miao, 2004; Wilson and Bruner, 2004; Foster and Heckert, 2011). Thus, a comparison of the Almada Fauna with contemporaneous Laurasian ichthyofaunas is not possible. Among the Jurassic fish assemblages from Gondwana, the fishes from the Early Jurassic Kota Formation, India, include two hybodontoid sharks, one coelacanth, two dapediids, two ginglymodians, and two possible halecomorphs (Prasad et al., 2004; López-Arbarello et al., 2008). The continental part of the Stanleyville Group in the Democratic Republic of Congo (Late Jurassic-Early Cretaceous; Myers et al., 2011) has yielded mawsoniid coelacanths, two basal neopteygians of uncertain relationships, a ginglymodian, and several basal teleosts or teleosteomorphs (SaintSeine and Casier, 1962; Taverne, 2011a, 2011b). In South America, the Late Jurassic-earliest Cretaceous? Tacuarembó Formation of Uruguay includes a paleoichthyofauna represented by hybodontid sharks (Perea et al., 2001), ceratodontiform dipnoans (Soto and Perea, 2010), a mawsonid coelacanth (Soto et al., 2012) and ginglymodians (Walther, 1932; López-Arbarello et al., 2008; Perea et al., 2009). In contrast, the Almada Fauna includes one species of teleost, †Luisiella feruglioi, the chondrostean †Condorlepis groeberi, and poorly preserved basal actinopterygians of uncertain relationships. Therefore, even though the relationships among the teleosts and teleosteomorphs present in all these faunas are still unknown, the absence of chondrichtyans, coelacanths, dipnoans, and ginglymodians, and the presence of a chondrostean make the composition of the Almada Fauna notably different from the above mentioned Jurassic freshwater fish faunas of Gondwana.

In contrast, the fish fauna of the Cañadón Calcáreo Formation is remarkably similar to that of the Talbragar Beds in Australia (Woodward, 1895). The Talbragar Fauna also includes a single teleost, †Cavenderichthys talbragarensis (Woodward, 1895), a single chondrostean, †Coccolepis australis Woodward, 1895, four teleosteomorph ("pholidophoriformes") aphnelepid species (†Aphnelepis australis, †Aetheolepis mirabilis, †Archaeomaene tenuis and †Madariscus robustus) and one fragmentary remain of a coelacanth. Also, the geological settings and taphonomic background of the two faunas are similar. The Talbragar fishes also occur in a single horizon within the stratigraphic column, representing an event of mass mortality due to volcanic activity within a freshwater environment (Bean, 2006).

†Luisiella feruglioi shares very similar morphological features with †Cavenderichthys talbragarensis and the two species are phylogenetically closely related (Sferco and LópezArbarello, 2010). Furthermore, †Condorlepis groeberi and + Coccolepis australis are members of the same chondrostean family Coccolepididae, and a thorough revision of the latter species might suggest that it is closely related to the Almada coccolepidid. These systematic affinities suggest close biogeographic relationships between the Argentinean and the Australian localities. Whether this similarity indicates the presence of a distinctive Middle-Late Jurassic southern Gondwanan (Patagonia-Antarctica[?]-Australia) fish fauna (maybe determined by latitudinal setting) or might simply have palaeoenvironmental reasons can only be tested by the discovery of new freshwater fish faunas from that age.

\section{ACKNOWLEDGEMENTS}

The authors are deeply grateful to E. Ruigómez for his permanent assistant including the best mate of Trelew. Thanks are extended to A. Báez, S. M. Alvarez and A. Kramarz for assistance during work at the MACN. Special thanks are due to E. Hilton and S. Štamberg for their valuable suggestions and criticisms on an early version of the article. The research has been financed by the German Research Foundation (http://www.dfg.de/) through the projects DFG Ra 1012/9-1 to O. Rauhut and DFG LO1405/3-1 to A. LópezArbarello. E. Sferco has been financed by the Consejo Nacional de Investigaciones Científicas y Técnicas, Argentina, and the German Academic Exchange Service (DAAD), Germany.

\section{REFERENCES}

Agassiz, L. 1833-1844. Recherches sur les Poissons Fossiles. Petitpierre, Neuchâtel et Soleure.

Bean, L.B. 2006. The leptolepid fish Cavenderichthys talbragarensis (Woodward, 1895) from the Talbragar Fish Bed (Late Jurassic) near Gulgong, New South Wales. Records of the Australian Museum, 23:43-76. 
Berg, L.S. 1940. Classification of Fishes Both Recent and fossil. Reprint edition with English translation (1965). Thai National Document Center, Bangkok.

Bocchino, A. 1967. Luisiella inexcutata gen. et. sp. nov. (Pisces, Clupeiformes, Dussumieridae) del Jurásico superior de la Provincia de Chubut, Argentina. Ameghiniana, 4:91-100.

Bocchino, A. 1978. Revisión de los Osteichthyes fósiles de la República Argentina. Identidad de Tharrias feruglioi Bordas, 1943 y Oligopleurus groeberi Bordas, 1943. Ameghiniana, 15:301-320.

Bordas, A.F. 1943. Peces del Cretácico del Río Chubut (Patagonia). Physis, 19:313-318.

Cabaleri, N.G. and Armella, C. 2005. Influence of biohermal belt on the lacustrine sedimentation of the Cañadón Asfalto Formation (Upper Jurassic, Chubut province, Southern Argentine). Geologica acta, 3:205-214.

Cabaleri, N.G., Armella, C., and Silva Neto, D.G. 2005. Saline lakes of Cañadón Asfalto Formation (MiddleUpper Jurassic), Cerro Cóndor, Chubut Province (Patagonia), Argentina. Facies, 51:350-364.

Cabaleri, N.G., Volkheimer, W., Silva Nieto, D.G., Armella, C., Cagnoni, M., Hauser, N., Matteini, M., and Pimentel, M.M. 2010b. U-Pb ages in zircons from Las Chacritas and Puesto Almada members of the Jurassic Cañadón Asfalto Formation, Chubut province, Argentina. South American Symposium on Isotope Geology, Brasilia, Abstracts:190-193.

Cabaleri, N.G., Volkheimer, W., Armella, C., Gallego, O., Silva Nieto, D., Páez, M., Cagnoni, M., Ramos, A., Paranello, H., and Koukharsky, M. 2010a. Estratigrafía, análisis de facies y paleoambientes de la Formación Cañadón Asfalto en el depocentro jurásico Cerro Cóndor, provincia del Chubut. Revista de la Asociación Geológica Argentina, 66:349-367.

Carballido, J.L., Rauhut, O.W.M., Pol, D., and Salgado, L. 2011. Osteology and phylogenetic relationships of Tehuelchesaurus benitezii (Dinosauria, Sauropoda) from the Upper Jurassic of Patagonia. Zoological Journal of the Linnean Society, 163:605-662.

Chang, M.M. and Miao, D. 2004. An overview of Mesozoic fishes in Asia, p. 535-563. In Arratia, G. and Tintori, A. (eds), Mesozoic Fishes 3 - Systematics, Paleoenvironments and Biodiversity. Verlag Dr. Friedrich Pfeil, Munich.

Choudhury, A. and Dick, T.A. 1998. The historical biogeography of sturgeons (Osteichthyes: Acipenseridae): a synthesis of phylogenetics, palaeontology and palaeogeography. Journal of Biogeography, 25:623640.

Cione, A.L. and Pereira, S.M. 1987. Los peces del Jurásico de Argentina. El Jurásico anterior a los movimientos intermálmicos, p. 287-298. In Volkheimer, W. (ed.), Bioestratigrafía de los sistemas Regionales del Jurásico y Cretácico de América del Sur. Centro Regional de Investigaciones Científicas y Técnicas, Mendoza.
Cope, E.D. 1871. Contribution to the ichthyology of the Lesser Antilles. Transactions of the American Philosophical Society, 14:445-483.

Cope, E.D. 1887. Zittel's Manual of Paleontology. American Naturalist, 21:1014-1019.

Cortiñas, J.S. 1996. La Cuenca Somuncurá-Cañadón Asfalto: sus límites, ciclos evolutivos del relleno sedimentario y posibilidades exploratorias. 12 Congreso Geológico Argentino y 3 Congreso de Exploración de Hidrocarburos, Actas I:147-163.

Cúneo, R., Ramezani, J., Scasso, R., Pol, D., Escapa, I., Zavattieri, A.M., Bowring, S.A. 2013. High-precision $\mathrm{U}-\mathrm{Pb}$ geochronology and a new chronostratigraphy for the Cañadón Asfalto Basin, Chubut, central Patagonia: Implications for terrestrial faunal and floral evolution in Jurassic. Gondwana Research, doi: 10.1016/j.gr.2013.01.010

Figari, E.G. 2005. Evolución tectónica de la Cuenca de Cañadón Asfalto (Zona del valle medio del Río Chubut). Unpublished PhD thesis, Universidad de Buenos Aires, Buenos Aires, Argentina.

Figari, E.G. and Courtade, S.F. 1993. Evolución tectosedimentaria de la Cuenca Cañadón Asfalto, Chubut, Argentina. $12^{\circ}$ Congreso Geológico Argentino y $2^{\circ}$ Congreso de Exploración de Hidrocarburos, Mendoza, Actas 1:66-77.

Foster, J.R. and Heckert, A.B. 2011. Ichthyoliths and other microvertebrate remains from the Morrison Formation (Upper Jurassic) of northeastern Wyoming: A screen-washed sample indicates a significant aquatic component to the fauna. Palaeogeography, Palaeoclimatology, Palaeoecology, 305:264-279.

Gallego, O.F., Cabaleri, N.G., Armella, C., Volkheimer, W., Ballent, S.C., Martínez, S., Monferran, M.D., Silva Nieto, D.G., and Páez, M.A. 2011. Paleontology, sedimentology and paleoenvironment of a new fossiliferous locality of the Jurassic Cañadón Asfalto Formation, Chubut Province, Argentina. Journal of South American Earth Sciences, 31:54-68.

Gorizdro-Kulczycka, F. 1926. Ryby słancev Karatau. Izvestia Sredne-azjatskogo Komiteta, 1:184-192.

Grande, L. and Bemis, W.E. 1991. Osteology and phylogenetic relationships of fossil and Recent paddlefishes (Polyodontidae) with comments on the interrelationships of Acipenseriformes. Society of Vertebrate Paleontology Memoir 1: 1-121; supplement to Journal of Vertebrate Paleontology 11(1).

Grande, L. and Bemis, W.E. 1996. Interrelationships of Acipenseriformes, with comments on "Chondrostei," p. 85-115. In Stiassny, M., Parenti, L., and Johnson, G.D. (eds.), Interrelationships of Fishes. Academic Press, San Diego.

Grande, L. and Hilton, E.J. 2006. An exquisitely preserved skeleton representing a primitive strugeon from the Upper Cretaceous Judith River Formation of Montana (Acipenseriformes: Acipenseridae: n. gen. and sp.). Journal of Paleontology, 80:1-39. 
Grande, L., Jin, F., Yabumoto, Y., and Bemis, W.E. 2002. Protopsephurus liui, a well-preserved primitive paddlefish (Acipenseriformes: Polyodontidae) from the Lower Cretaceous of China. Journal of Vertebrate Paleontology, 22:209-237.

Gradstein, F.M., Ogg, J.G., Smith, A.G., Agterberg, F.P., Bleeker, W., Cooper, R.A., Davydov, V., Gibbard, P., Hinnov, L.A., House, M.R., Lourens, L., Luterbacher, H.P., McArthur, J., Melchin, M.J., Robb, L.J., Shergold, J., Villeneuve, M., Wardlaw, B.R., Ali, J., Brinkhuis, H., Hilgen, F.J., Hooker, J., Howarth, R.J., Knoll, A.H., Laskar, J., Monechi, S., Plumb, K.A., Powell, J., Raffi, I., Röhl, U., Sadler, P., Sanfilippo, A., Schmitz, B., Shackleton, N.J., Shields, G.A., Strauss, H., Van Dam, J., van Kolfschoten, T., Veizer, J., and Wilson, D. 2004. A geologic time scale 2004. Cambridge University Press, Cambridge.

Hilton, E.J. 2002. Observations on Rostral Canal Bones of Two Species of Acipenser (Actinopterygii, Acipenseriformes). Copeia 2002:213-219.

Hilton, E.J. and Forey, P.L. 2009. Redescription of †Chondrosteus acipenseroides Egerton, 1858 (Acipenseriformes, †Chondrosteidae) from the Lower Lias of Lyme Regis (Dorset, England), with comments on the early evolution of sturgeons and paddlefishes. Journal of Systematic Palaeontology, 7:427-453.

Hilton, E.J. and Grande, L. 2006. Review of the fossil record of sturgeons, family Acipenseridae (Actinopterygii: Acipenseriformes), from North America. Journal of Paleontology, 80:672-683.

Hilton, E.J., Grande, L., and Bemis, W.E. 2004. Morphology of Coccolepis bucklandi Agassiz 1843 (Actinopterygii) from the Solnhofen lithographic limestone deposits (Late Jurassic, Germany), p. 209-238. In Arratia, G. and Tintori, A. (eds.), Mesozoic Fishes 3 Systematics, Paleoenvironments and Biodiversity. Verlag Dr. Friedrich Pfeil, Munich.

Hilton, E.J., Grande, L., and Bemis, W.E. 2011. Skeletal anatomy of the shortnose sturgeon, Acipenser brevirostrum Lesueur, 1818, and the Systematics of Sturgeons (Acipenseriformes, Acipenseridae). Fieldiana Life and Earth Sciences, 3:1-168.

Jollie, M. 1980. Development of head and pectoral girdle skeleton and scales in Acipenser. Copeia, 1980 (2):226-249.

Kirkland, J.I. 1998. Morrison Fishes. Modern Geology, 22:503-533.

Liu, T.-S. 1957. A New Cretaceous Paleoniscoid Fish from Yumen of the Chiuchuan Basin, Western Kansu. Vertebrata Pal Asiatica, 1:103-122.

López-Arbarello, A. 2004. The record of Mesozoic fishes from Gondwana (excluding India and Madagascar), p. 597-624. In Arratia, G. and Tintori, A. (eds.), Mesozoic Fishes 3 -Systematics, Paleoenvironments and Biodiversity. Verlag Dr. Friedrich Pfeil, Munich.

López-Arbarello, A. 2012. Phylogenetic Interrelationships of Ginglymodian Fishes (Actinopterygii: Neopterygii). PLoS ONE, 7:e39370.
López-Arbarello, A., Arratia, G., and Codorniú, L. 2002. The coccolepidids from South America and the early history of Chondrostei. Journal of Vertebrate Paleontology, 22:80A.

López-Arbarello, A., Rauhut, O.W.M., and Moser, K. 2008. Jurassic fishes of Gondwana. Revista de la Asociación Geológica Argentina, 63:586-612.

Müller, J. 1844. Über den Bau und die Grenzen der Ganoiden und über das natüerliche System der Fische. Bericht über die zur Bekanntmachung geeigneten Verhandlungen der Akademie der Wissenschaften, Berlin, 1846:117-216.

Myers, T.S., Tabor, N.J., and Jacobs, L.L. 2011. Late Jurassic paleoclimate of Central Africa. Palaeogeography, Palaeoclimatology, Palaeoecology, 311:111125.

Nielsen, E. 1949. Studies on Triassic fishes from East Greenland. II. Australosomus and Birgeria. Meddelelser om Grønland, Kommissionen for Videnskabelige Undersøgelser I Grønland, 146:1-309.

Page, R., Ardolino, A., De Barrio, R.E., Franchi, M., Lizuain, A., Page, S., and Silva Nieto, D. 1999. Estratigrafía del Jurásico y Cretácico del Macizo de Somún Curá, provincias de Río Negro y Chubut, p. 460-488. In Caminos, R. (ed.), Geología Regional Argentina, Servicio Geológico Minero Argentino. Instituto de Geología y Recursos Minerales, Anales 29.

Patterson, C. 1982. Morphology and interrelationships of primitive actinopterygian fishes. American Zoologist, 22:241-259.

Perea, D., Ubilla, M., Rojas, A., and Goso, C.A. 2001. The newest Gondwanan occurrence of the hybodontid shark Priohybodus, and the Late Jurassic-Early Cretaceous age of the Tacuarembó Formation, Uruguay. Palaeontology, 44:1227-1235.

Perea, D., Soto, M., Veroslavsky, G., Martínez, S., and Ubilla, M. 2009 A Late Jurassic fossil assemblage in Gondwana: biostratigraphy and correlations of the Tacuarembó Formation, Parana Basin, Uruguay. Journal of South American Earth Sciences, 28:169179.

Piatnitzky, C. 1936. Informe preliminar sobre el estudio geológico de la región situada al norte de los lagos Colhué Huapi y Musters. Boletín Informaciones Petroleras, Yacimientos Petrolíferos Fiscales, Buenos Aires, 137:2-15.

Pol, D., Rauhut, O.W.M., Lecuona, A., and Leardi, J.M. 2011. A new basal crocodylomorph from the Late Jurassic of Patagonia and its implications for the evolution of the crocodyliform braincase. Journal of Vertebrate Paleontology, 31:175.

Prasad, G.V.R., Manhas, B.K., and Arratia, G. 2004. Elasmobranch and actinopterygian remains from the Jurassic and Cretaceous of India, p. 625-638. In Arratia, G. and Tintori, A. (eds.), Mesozoic Fishes 3 Systematics, Paleoenvironments and Biodiversity. Verlag Dr. Friedrich Pfeil, Munich. 
Proserpio, C.A. 1987. Descripción Geológica de la Hoja 44e, Valle General Racedo. Dirección Nacional de Minería y Geología, Boletín 201, Buenos Aires.

Rauhut, O.W.M. 2003. A dentary of Patagosaurus (Sauropoda) from the Middle Jurassic of Patagonia. Ameghiniana, 40:425-432.

Rauhut, O.W.M. 2006a. A brachiosaurid sauropod from the Late Jurassic Cañadón Calcáreo Formation of Chubut, Argentina. Fossil Record, 9:226-237.

Rauhut, O.W.M. 2006b. Dinosaurier aus dem oberen Jura Südamerikas. Freunde der Bayerischen Staatssammlung für Paläontologie und Historische Geologie e.V., Jahresbericht und Mitteilungen, 34:56-70.

Rauhut, O.W.M., Remes, K., Fechner, R., Cladera, G., and Puerta, P. 2005. Discovery of a short-necked sauropod dinosaur from the Late Jurassic period of Patagonia. Nature, 435:670-672.

Rich, T.H., Vickers-Rich, P., Gimenez, O., Cúneo, R., Puerta, P., and Vacca, R. 1999. A new sauropod dinosaur from Chubut Province, Argentina. National Science Museum Monographs, 15:61-84.

Saint-Seine, P. 1950. Contribution à l'étude des vertébrés fossiles du Congo Belge. Annales du Musée Royal du Congo Belge, Tervuren (Belgique), Série in- $8^{\circ}$, Sciences Géologiques, 5:1-32.

Saint-Seine, P. 1955. Poissons fossiles de l'étage de Stanleyville (Congo belge). Premiere Partie: La Faune des argilites et schistes bitumineux. Annales du Musée Royal du Congo Belge Tervuren (Belgique), Série in- $8^{\circ}$, Sciences géologiques, 14:1-126.

Saint-Seine, M.P. and Casier, E. 1962. Poissons fossiles des couches de Stanleyville (Congo). Annales du Musee Royal de L'Afrique Centrale, Tervuren, Belgique, Serie in $8^{\circ}$, Sciences Geologiques, 44:1-52.

Schultze, H.P. 1966. Morphologische und histologische untersuchungen an Schuppen Mesozoischer Actinopterygier (Übergang von Ganoid- zu Rundschuppen). Neues Jahrbuch für Geologie und Paläontologie, Abhandlungen, 126:232-314.

Schultze, H.P. and Arratia, G. 1989. The composition of the caudal skeleton of teleosts (Actinopterygii: Osteichthyes). Zoological Journal of the Linnean Society, 97:189-231.

Sferco, E. 2011. Resolving the taxonomy of 'Tharrias' feruglioi, a Late Jurassic basal teleost (Actinopterygii) from Patagonia. Ameghiniana 48(4):R240-R241.

Sferco, E. and López-Arbarello, A. 2010. Southern Gondwanan Late Jurassic continental teleosts (Actinopterygii, Teleostei): phylogeny and biogeography. Actas del $X$ Congreso Argentino de Paleontología y Bioestratigrafía y $V$ Congreso Latinoamericano de Paleontología, Libro de Resúmenes: p. 209.

Silva Nieto, D., Cabaleri, N. and Salani, F.M. 2003. Estratigrafía de la Formación Cañadón Asfalto (Jurásico Superior) provincia del Chubut. Ameghiniana, 40(4) Suplemento: 46R.
Silva Nieto, D., Cabaleri, N., Salani, F., Márquez, M., González Díaz, E., and Coluccia, A. 2002. Hoja Geológica 4369-27 Cerro Cóndor, Provincia del Chubut. Instituto de Geología y Recursos Minerales, Servicio Geológico Minero Argentino, Boletín N 328, Buenos Aires.

Soto, M. and Perea, D. 2010. Late Jurassic lungfishes (Dipnoi) from Uruguay, with comments on the systematics of Gondwanan ceratodontiforms. Journal of Vertebrate Paleontology, 30:1049-1058.

Soto, M., De Carvalho, M.S.S., Maisey, J.G., Perea, D., and Da Silva, J. 2012. Coelacanth remains from the Late Jurassic-?earliest Cretaceous of Uruguay: the southernmost occurrence of the Mawsoniidae. Journal of Vertebrate Paleontology, 32:530-537.

Stensïo E. 1921. Triassic Fishes from Spitzbergen. Part I. A. Holzhausen, Wien.

Stensiö, E. 1932. Triassic fishes from east Greenland collected by the Danish Expeditions in 1929-1931. Meddelelser om Grønland, 83:1-305.

Sterli, J. 2009. Sistemática y paleobiogeografía de las tortugas continentales del Jurásico de Patagonia. Unpublished PhD thesis, Universidad Nacional de La Plata, La Plata, Argentina.

Stipanicic, P.N., Rodrigo, F., Baulíes, O., and Martínez, C. 1968. Las formaciones presenonianas en el denominado Macizo Nord-Patagónico y regiones adyacentes. Revista de la Asociación Geológica Argentina, 23:67-98.

Sytchevskaya, E.K. 2006. lyalepis nom. nov., a new replacement name for Angaqrichthys Sytchevskaya et Yakovlev, 1985 (Pisces, Palaeonisciformes, Coccolepididae). Paleontological Journal, 40:339.

Tasch, P. and Volkheimer, W. 1970. Jurassic conchostracans from Patagonia. Kansas University, Paleontological Contribution Paper 50:1- 23, Kansas.

Taverne, L. 2011a. Ostéologie et relations de Steurbautichthys ("Pholidophorus") aequatorialis gen. nov. (Teleostei, "Pholidophoriformes") du Jurassique moyen de Kisangani (Formation de Stanleyville, Calcaires de Songa) en République Démocratique du Congo. Bulletin de I'Institut Royal des Sciences Naturelles de Belgique, Sciences de la Terre, 81:129-173.

Taverne, L. 2011b. Ostéologie et relations phylogénétiques de Catervariolus (Teleostei, "Pholidophoriformes") du Jurassique moyen de Kisangani en République Démocratique du Congo. Bulletin de l'Institut Royal des Sciences Naturelles de Belgique, Sciences de la Terre, 81:175-212.

Traquair, R.H. 1911. Les poissons wealdiens de Bernissart. Mémoires du Musée royal d'Histoire naturelle de Belgique, 21:1-65.

Turner, J.C. 1983. Descripción geológica de la Hoja 44d, Colan Conhué. Dirección Nacional de Minería y Geología, Boletín 197, Buenos Aires. 
Volkheimer, W., Quattrocchio, M., Cabaleri, N.G., and García, V. 2008. Palynology and paleoenvironment of the Jurassic lacustrine Cañadón Asfalto Formation at Cañadón Lahuincó locality, Chubut Province, Central Patagonia, Argentina. Revista Española de Micropaleontología, 40:77-96.

Volkheimer, W., Gallego, O.F., Cabaleri, N.G., Armella, C., Narváez, P.L., Silva Nieto, D.G., and Páez, M.A. 2009. Stratigraphy, palynology, and conchostracans of a Lower Cretaceous sequence at the Cañadón Calcáreo locality, Extra-Andean central Patagonia: age and palaeoenvironmental significance. Cretaceous Research, 30:270-282.

Waldman, M. 1971. Fish from the freshwater Lower Cretaceous of Victoria, Australia with comments on the palaeo-environment. Special Papers in Palaeontology, 9:1-62.

Walther, K. 1932. Über Reste eines grossen Ganoidfische aus dem Obergondwana von Uruguay. Zentralblatt für Mineralogie, Geologie und Paläontologie, B9:449-461.

Wang, 1977. Jurassic Fish and their Stratigraphic significance from the Hengyang Region of Lingling Co., Hunan Province. Vertebrata PalAsiatica, 15:233-243.
Wilson, M.V.H. and Bruner, J.C. 2004. Mesozoic Fish Assemblages of North America, p. 575-595. In Arratia, G. and Tintori, A. (eds.), Mesozoic Fishes 3 Systematics, Paleoenvironments and Biodiversity. Verlag Dr. Friederich Pfeil, Munich.

Woodward, A.S. 1890. Notes on some ganoid fishes from the English lower Lias. The Annals and Magazine of Natural History, Sixth Series, 5:430-436.

Woodward, A.S. 1891. On the paleontology of sturgeons. Proceedings of the Geological Association, 11:24-45.

Woodward, A.S. 1895. The fossil fishes of the Talbragar Beds (Jurassic?). Memoirs 50 of the Geological Survey of New South Wales, Palaeontology, 9:1-27.

Woodward, A.S. 1915. The fossil fishes of the English Wealden and Purbeck formations. The Palaeontographical Society.

Woodward, A.S. and Sherborn, C.D. 1890. A Catalogue of British Fossil Vertebrata. Dulao \& Company, London.

Zavattieri, A.M., Escapa, I.H., Scasso, R.A., and Olivera, D. 2010. Contribución al conocimiento palinoestratigráfico de la Formación Cañadón Calcáreo en su localidad tipo, provincia del Chubut, Argentina. $X$ Congreso Argentino de Paleontología y Bioestratigrafía y VII Congreso Latinoamericano de Paleontología, Libro de Resúmenes: 224. 